\title{
An attempt to estimate tolerable soil erosion rates by matching soil formation with denudation in Alpine grasslands
}

\author{
Christine Alewell • Markus Egli • Katrin Meusburger
}

Received: 17 December 2013 / Accepted: 29 May 2014 / Published online: 24 June 2014

(C) The Author(s) 2014. This article is published with open access at Springerlink.com

\begin{abstract}
Purpose Natural rates of soil production or a target soil thickness that allows unrestricted land use can serve as a basis for defining tolerable soil erosion rates. Guidelines for tolerable soil erosion rates in alpine grasslands do not yet exist, partly due to the lack of information of soil formation and production rates. We (i) defined soil formation/production rates for alpine grasslands on siliceous lithology and compared them to measured and modelled soil erosion rates and resulting soil thickness with a special focus on the Urseren Valley (Central Swiss Alps) and (ii) discussed possible trends for alpine soils under global change.

Materials and methods Ranges of soil formation, production and erosion rates were determined using published and our own data for Alpine grasslands soils. Two definitions of tolerable erosion rate were used: when (i) current soil depth remains constant over time; and (ii) at least a minimum soil depth is maintained (minimum thicknesses for individual land uses still need to be defined).

Results and discussion Soil production and related tolerable erosion rates (i.e. $50-90 \%$ of the soil production rate) are a strong function of time. Average soil production rate in alpine areas for relatively old soils $(>10-18 \mathrm{kyr})$ is between $54( \pm 14)$ and $113( \pm 30) \mathrm{t} \mathrm{km}^{-2}$ year $^{-1}$, for young soils $(>1-10 \mathrm{kyr})$ between $119( \pm 44)$ and $248( \pm 91) \mathrm{t} \mathrm{km}^{-2}$ year $^{-1}$ and for very
\end{abstract}

Responsible editor: Arnaud Temme

Christine Alewell and Markus Egli shared first authorship

C. Alewell $(\bowtie) \cdot K$. Meusburger

Environmental Geosciences, Department of Environmental Sciences, University of Basel, Bernoullistr. 30, 4056 Basel, Switzerland

e-mail: christine.alewell@unibas.ch

\section{Egli}

Department of Geography, University of Zürich,

Winterthurerstrasse 190, 8057 Zürich, Switzerland

e-mail: markus.egli@geo.uzh.ch young soils $(\leq 1 \mathrm{kyr})$ between $415( \pm 242)$ and $881( \pm 520)$ $\mathrm{t} \mathrm{km}^{-2}$ year $^{-1}$. Measured recent soil erosion rates in alpine areas at intensively used slopes range from 600 to $3000 \mathrm{t} \mathrm{km}^{-2}$ year $^{-1}$. Average catchment values for the Urseren Valley using the model USLE plus soil loss due to landslides resulted in an overall loss of $180 \mathrm{t} \mathrm{km}^{-2}$ year $^{-1}$, which considerably exceeds production rates of the soils.

Conclusions The comparison of soil production and erosion rates indicated unsustainable management of grassland soils in the Urseren Valley. Other Alpine regions report similar or even higher erosion rates. Consequently, attention has to be paid to Alpine grasslands used for agricultural purposes because today's soil erosion rates often considerably exceed soil formation, thus resulting in very shallow soils. Future global change is likely to increase soil erosion rates even further.

Keywords Alps $\cdot$ Soil loss $\cdot$ Soil production .

Sustainable land use

\section{Introduction}

Alpine soils are an often overlooked and undervalued resource. They deliver services such as wood and grass production, cattle and sheep farming, hydrological services (flood prevention, drinking water supply) and last but not least recreational services. Grassland is the dominant land-use type in the Alps at altitudes above $1500 \mathrm{~m}$ asl (BFS 2005). Soil degradation in Alpine grasslands is mostly due to three processes: (i) shallow landslide activity, which is a mass movement of soil volume; (ii) sheet erosion, which is a gradual detachment and transport of single soil grains and aggregates and (iii) livestock trails caused by trampling of cattle or sheep, which give rise to horizontal structures (Fig. 1). The horizontal structuring of the slopes due to livestock trails may sometimes have contrasting effects: it might trigger landslides and 
Fig. 1 Main forms of soil degradation in the Urseren Valley: landslides, sheet erosion and livestock trails

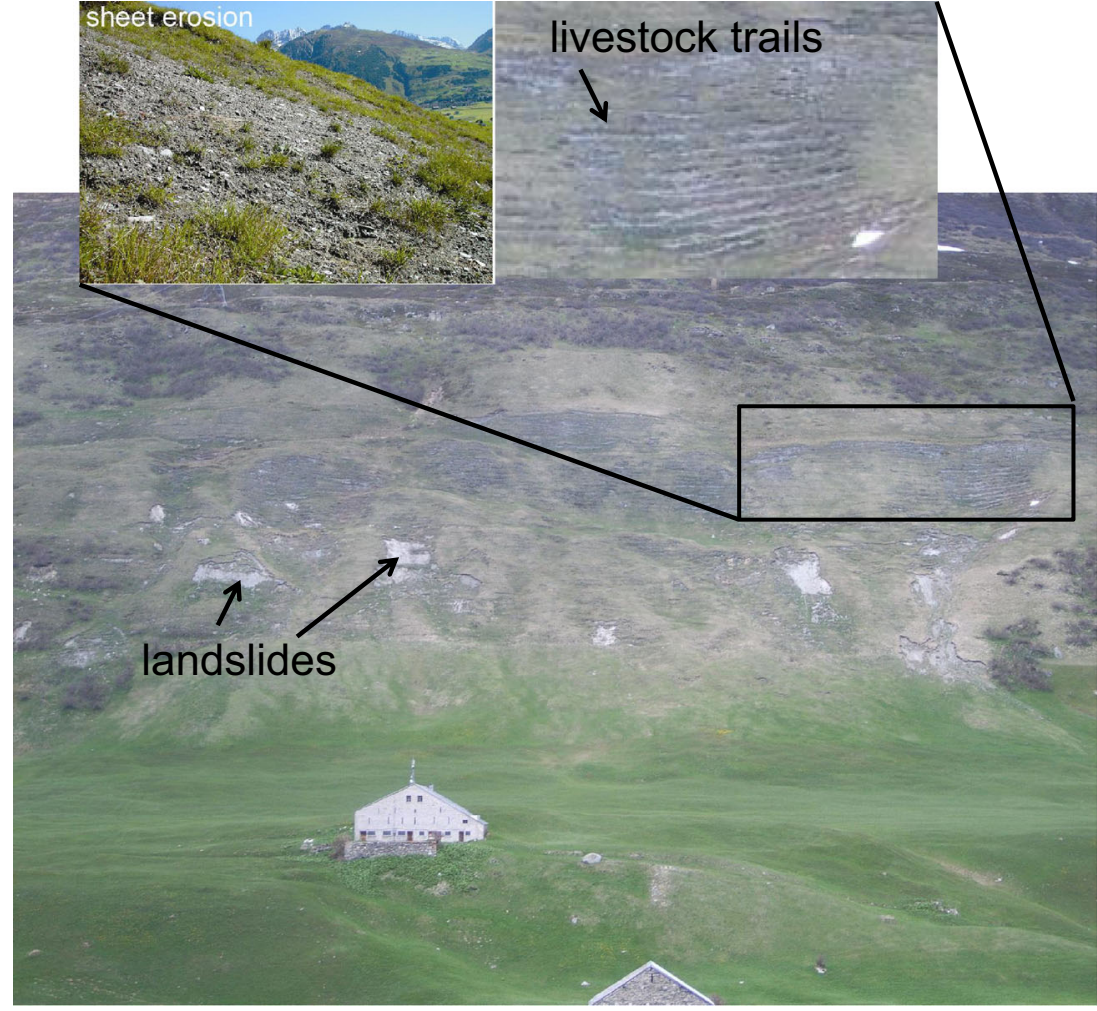

increase sheet erosion due to the damaged vegetation: it might, however, also decrease sheet erosion by interrupting slope length and thus Hortonian overland flow. Differentiating between these three processes is crucial for an assessment of the extent of deterioration or, vice versa, of finding possibilities to attain sustainable management. While landslide dynamics are the most visible degradation - and thus the degradation form that is paid most attention to-it is often the smaller on-site effect in Alpine valleys from a quantitative soil-loss perspective (Meusburger and Alewell 2008).

Generally, soil erosion susceptibility assessments assume a homogenous behaviour of grassland. However, soil erosion rates are not only dependent on soil characteristics like soil texture, organic content, soil structure and root density that enhance soil strength, but also depend on land use and vegetation cover (Alewell et al. 2008; Konz et al. 2009; Meusburger et al. 2010). The heterogeneity and magnitude of soil erosion rates in alpine grasslands varies considerably from marginal rates in intact grasslands up to $1,400 \mathrm{t} \mathrm{km}^{-2}$ year $^{-1}$ (Alewell et al. 2014) or even $>3,000 \mathrm{t} \mathrm{km}^{-2}$ year $^{-1}$ (Konz et al. 2009) at steep slopes affected by livestock trampling and/or snow and freezing processes: the latter leads to soil compaction and/or vegetation removal and subsequently to increased erosion rates.

We use the soil-loss tolerance value (permissible soil loss or soil sustainability) as a basis for judging whether a soil has a potential risk for productivity loss or generally for soil degradation. Tolerance values also serve as an ultimate criterion for erosion control or as a proxy indicator of soil quality (Johnson 1987; Li et al. 2009) to preserve long-term soil productivity and environmental security. A modified definition of tolerable soil erosion was proposed by Verheijen et al. (2009) as 'any actual soil erosion rate at which a deterioration or loss of one or more soil functions does not occur' - actual soil erosion being 'the total amount of soil lost by all recognised erosion types.'

When discussing sustainability of soil use and management, it is crucial to know the rates of soil formation and production that are the counteracting processes to soil erosion. Natural rates of soil formation can be used as a basis for setting tolerable soil erosion rates, with soil formation consisting of mineral weathering as well as dust deposition (Verheijen et al 2009). In mountain areas where soil depth is the main limiting factor for soil productivity, the use and management of soils must consider how to preserve them from excessive depth loss and consequent degradation of their physical, chemical and biological properties. Considering that some of the above criteria are soil-age dependent, fixed values for soil erosion tolerance (Grossman and Berdanier 1982) can only be valid for limited time periods. An erosion rate greater than the soil formation rate can be accepted until a certain soil depth is reached (the latter has still to be defined as a minimum tolerable soil depth), provided that the erosion rate is not associated with environmental hazards or productivity losses (Sparovek and Jong van Lier 1997). 
Consequently, when determining tolerable erosion rates, the temporal (and also spatial) variation of soil production and (time-dependent) losses have to be considered-but datasets are often lacking. Furthermore, the determination of soil formation or production rates for alpine sites is difficult. Rates of chemical weathering often exponentially decrease with increasing age of the soils (Dahms et al. 2012). Weathering rates were found to be three to four orders of magnitude lower in old soils ( $\sim 1$ million years) than in soils at an initial development stage (Dahms et al. 2012; Egli et al. 2014). As Alpine soils are in most cases younger than 20,000 years, soil formation rates are less uncertain. However, soils in alpine areas may have a complex evolution because they have developed on cover beds (Mailänder and Veit 2001; Waroszewski et al. 2013) or showed progressive and regressive evolutionary steps (e.g. Mourier et al 2010; Brisset et al. 2013).

Sustainable management of Alpine grassland soils has been impeded in the past by the lack of suitable guideline values for tolerable soil erosion as well as a lack of large-scale assessment of actual soil erosion rates. To be able to come to guideline values that might be useful management tools, tolerable soil-loss values that are counterbalanced by soil formation have to be assessed for Alpine regions. The aim of this study is to: (i) estimate soil formation and production rates in Alpine grasslands; (ii) compare them to published soil erosion rates with a special focus on the case study in the Urseren Valley (Canton Uri; Central Swiss Alps) and (iii) develop concepts of how guideline values for tolerable soil erosion rates can be derived.

\section{Site description}

Our study focuses on subalpine and alpine grasslands of the Swiss Central Alps in general with special emphasis on the Urseren Valley (Canton Uri, Switzerland, Fig. 2).

The climate in the Alps generally varies from temperate in the lower valley bottoms to subalpine and alpine at higher altitudes, and from semi-arid in some dry inner alpine valleys to humid with more than $4,000 \mathrm{~mm}$ annual precipitation in some regions of the Southern Alps. A wide variety of soils can

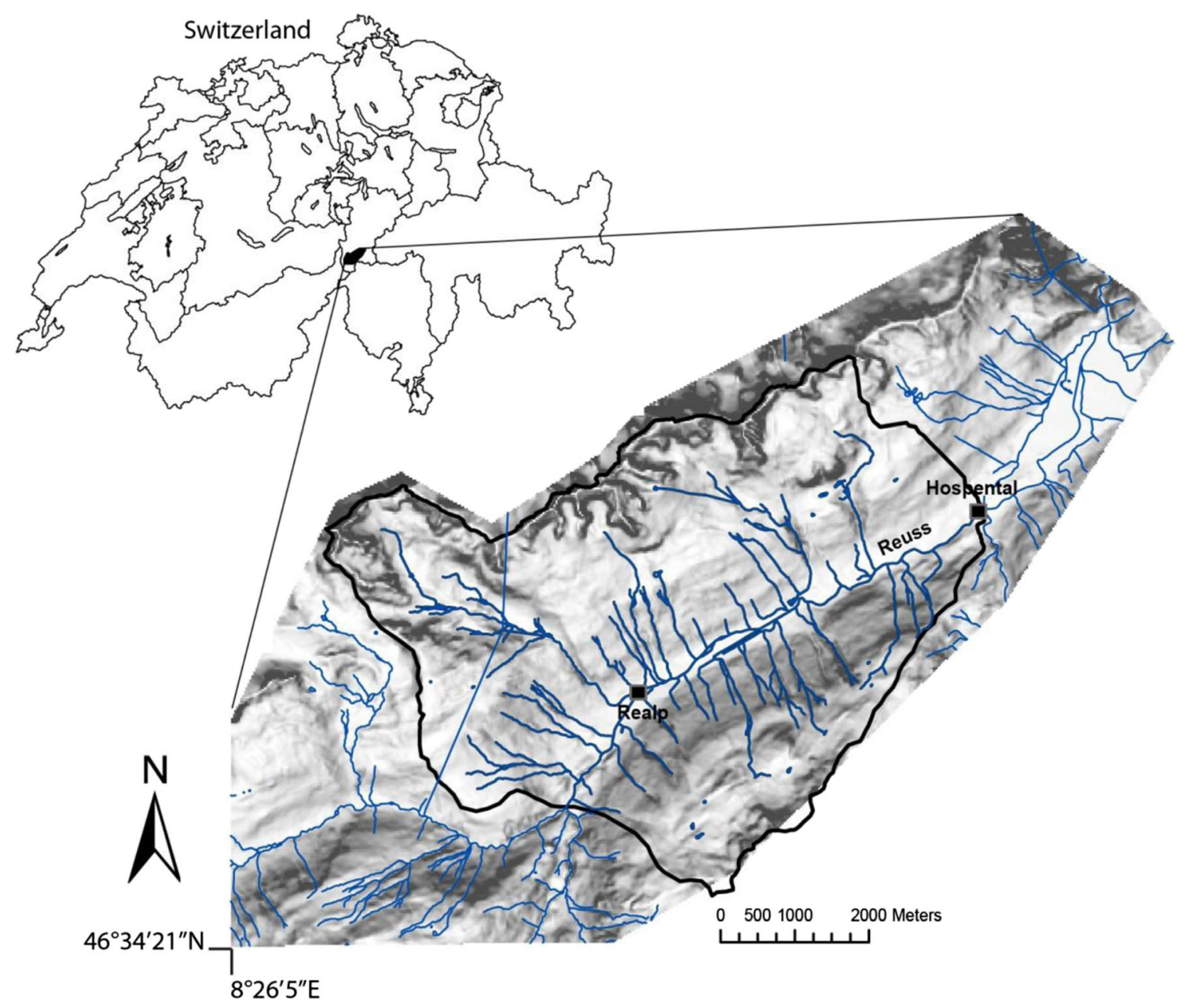

Fig. 2 Location of the Usern Valley, Central Swiss Alps 
be found from shallow Leptosols at mountain ridges or heavily eroding slopes to deeply developed Anthrosols (IUSS Working Group WRB 2007) at the lower slopes and valley bottoms (Anthrosols in this case describe soils that have been developed through centuries of sedimentation due to anthropogenic upslope deforestation and intensive agricultural activities). Depending on the underlying bedrock material, soils vary from calcareous to acidic podzolic soils. In this study, we assess soil development and erosion on siliceous parent material.

The Urseren Valley is glacially U-shaped and ranges from 1,400 to $3,200 \mathrm{~m}$ asl in altitude. The southern mountain ridge is built by the 'Gotthard massif' that mainly includes paragneiss and granite. The northern crests are formed by granite, granitoids, gneiss and migmatite of the Aare system, which is divided into the 'Aare granite' and the gneiss/ migmatite complex of the 'Altkristallin' (Labhart 1977). According to the world reference base (IUSS Working Group WRB 2007), dominant soil orders in the valley are Podzols and Cambisols (Meusburger and Alewell 2008). Leptosols can be found at higher elevations and on steeper slopes. Anthrosols, clayey gleyic Cambisols, Histosols, Fluvisols and Gleysols are common at the valley bottom and lower slopes.

Mean annual air temperature at the MeteoSwiss climate station in Andermatt (1,442 m asl, years 1980 to 2012) is $4.1 \pm$ $0.7^{\circ} \mathrm{C}$ and mean annual precipitation is $1,457 \pm 290 \mathrm{~mm}$, with $\sim 30 \%$ falling as snow (MeteoSwiss 2013). The period of snow cover is usually from November to April and runoff is dominated by snowmelt in May and June. These conditions are typical for subalpine to alpine sites in the European Alps. Vegetation shows strong anthropogenic influences due to pasturing for centuries (Kägi 1973). The encroachment of shrubs into formerly open habitats can be observed occasionally (Meusburger and Alewell 2008).

\section{Concepts and determination of soil formation and denudation}

\subsection{Concepts and approach}

\subsubsection{Soil production and formation}

Soil formation (or production) depends on the lithology, the development of organic matter, the rate of supply of fresh regolith through physical weathering and erosion, the age of exposure and the character of the hydrological system (Egli et al. 2014). This harks back to the fundamental concept of Dokuchaev (1883) and, in an extended form, of Jenny (1941) according to which soil formation is a function of the five factors 'time', 'climate', 'topography', 'organisms' and 'parent material'. These factors act together to influence the rate(s) and direction(s) of soil formation. In this work, we focus on soils developed on silicate parent materials (Egli et al. 2014).

Several terms regarding soil evolution have been used in a partially misleading way. The terms 'soil formation' and 'soil development' are considered to be synonymous (Egli et al. 2014). The term 'soil production' designates the gross production while 'soil formation' (or 'soil development') describes the net effect (Egli et al. 2014; see Fig. 3). Different techniques are available to derive soil production and soil formation rates in the field. Among them are (i) chronosequences (Sauer 2010; Sauer et al. 2010; Egli et al. 2014); (ii) isotopic techniques such as cosmogenic nuclides (often ${ }^{10} \mathrm{Be},{ }^{26} \mathrm{Al}$; Heimsath et al. 1997, 2012; Green et al. 2006; Riebe et al. 2004a, b etc.) and (iii) methods to determine the residence time of soil particles (e.g. ${ }^{230}$ thorium $/{ }^{234}$ uranium activity ratios; Dosseto et al. 2008, 2011, 2012; Ma et al. 2010).

Soil production describes the transformation of the parent material into soil (due to chemical and physical weathering, mineral transformation), the lowering of the bedrock (or parent material)/soil boundary (Heimsath et al. 1997, 2009) and the input of atmospheric deposition (Fig. 3).

Soil formation $\left(F_{\text {soil }}\right)$, as the net effect of soil mass changes (Fig. 4), can be expressed by:

$F_{\text {soil }}=P_{\text {soil }}-D_{\text {soil }}$

where $P_{\text {soil }}=$ soil production with $P_{\text {soil }}=T_{\text {soil }}+A$, thus including the transformation of the parent material or rock into soil

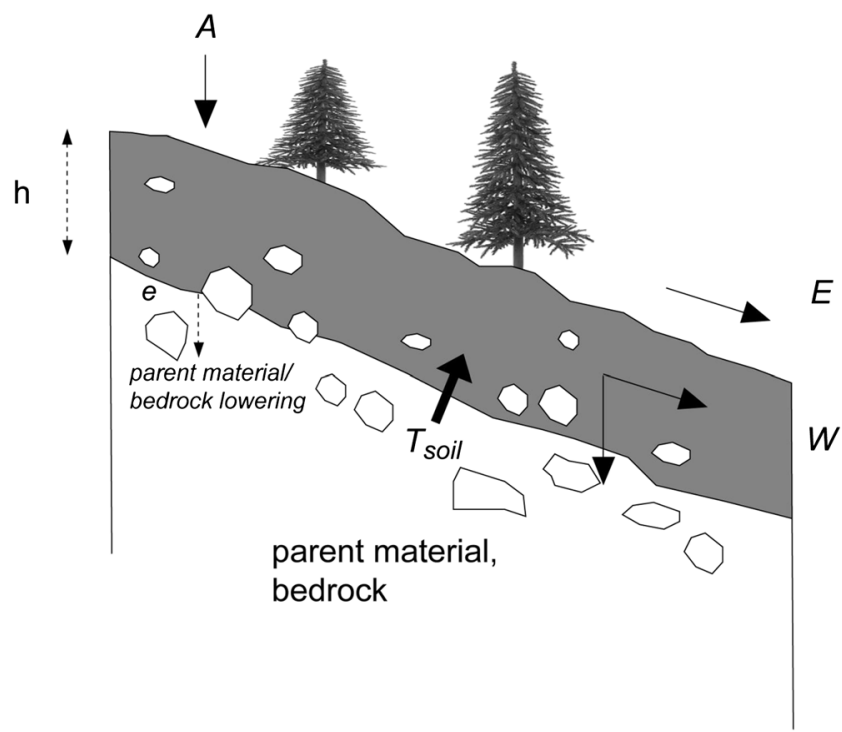

Fig. 3 Schematic overview of the evolution of a soil profile (Egli et al. 2014). Symbol e refers to the interface between bedrock (or parent material) and soil. $h$ is the soil thickness (that represents soil formation $\left(F_{\text {soil }}\right)$; see Eq. 1). Atmospheric input is given by $A$ and the transformation of parent material into soil by $T_{\text {soil }}$ (the sum of these parameters equals soil production; Eq. 1) 
Fig. 4 Schematic representation of soil formation $\left(F_{\text {soil }}\right)$, production $\left(P_{\text {soil }}\right)$ and denudation $\left(D_{\text {soil }}\right)$ as a function of time for three cases: a soil production is greater than total denudation (cf. Eq. 1) over time (one example for a time-trend is given) resulting in soil formation and a positive mass balance (Eq. 2); b denudation and soil production are equal which gives rise to no soil formation (three examples for a time-trend of $P_{\text {soil }}$ and $D_{\text {soil }}$ are given); and c denudation is greater than soil production leading to negative formation rates and a subsequent regressive soil evolution (cf. Sommer et al. 2008)
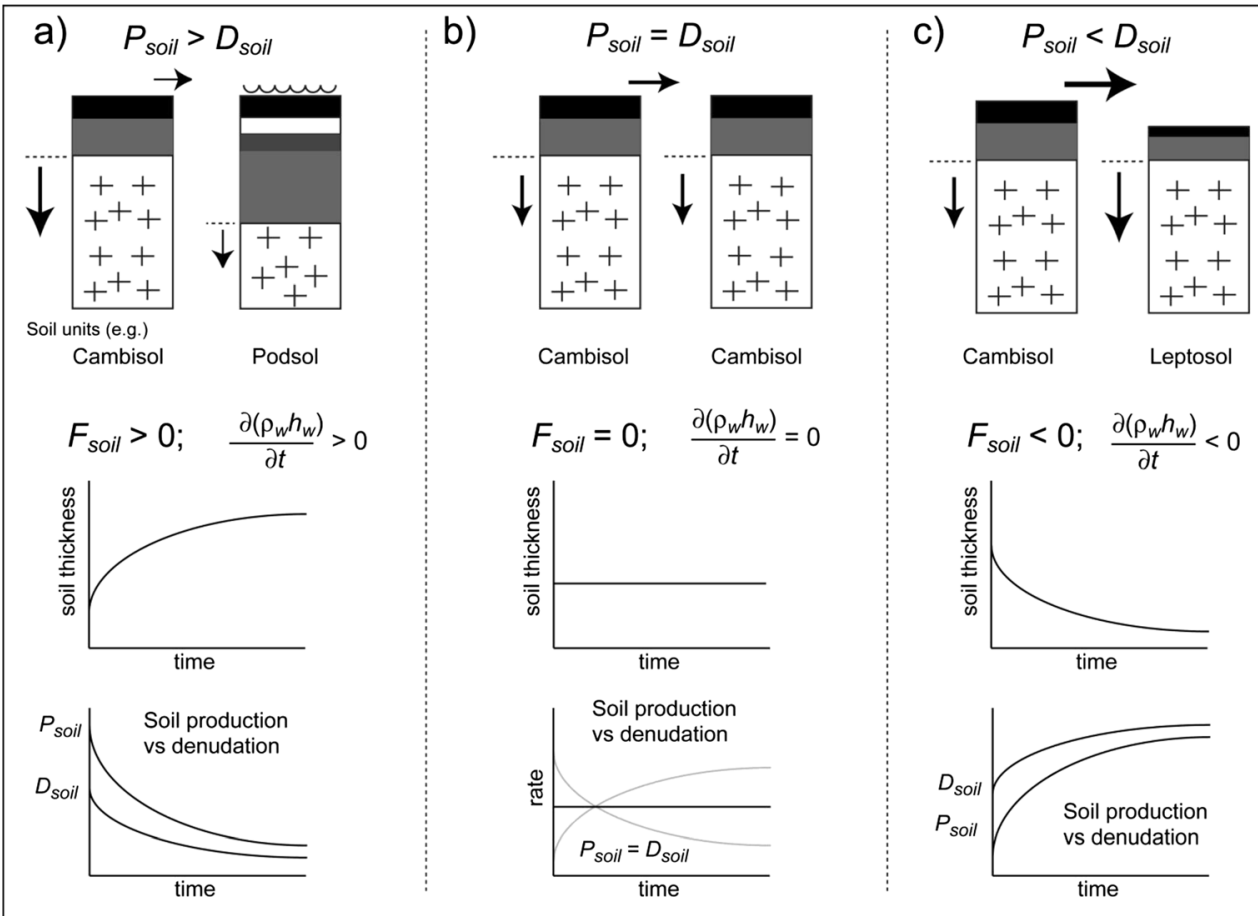

( $\left.T_{\text {soil }}\right)$ and atmospheric input (A). $D_{\text {soil }}$ is the total denudation (mass export or import by erosion; which in the case of import erosion has negative values) and chemical denudation (usually given in $\mathrm{t} \mathrm{km}^{-2}$ year $^{-1}$ ).

In a more extended way, changes in soil material mass can be expressed by:

$\frac{\partial\left(\rho_{w} h_{w}\right)}{\partial t}=\rho_{r} Q_{U A}-\nabla \cdot\left(\rho_{w} \overrightarrow{Q_{D}}\right)=\phi-\nabla q_{e}-\nabla q_{w}$

where $\rho=$ bulk density $\left[t / \mathrm{m}^{3}\right]$ (w: soil; r: parent material that also may be atmospheric input (loess)), $h_{\mathrm{w}}=$ soil material thickness [m], $Q_{\mathrm{UA}}=$ soil material mass (volume) production rate per unit area $\left[\mathrm{m}^{3} / \mathrm{m}^{2} / \mathrm{T}\right]$ ( $T=$ time), $Q_{\mathrm{D}}=$ denudation mass (volume) flux rate per unit area $\left[\mathrm{m}^{3} / \mathrm{m}^{2} / \mathrm{T}\right], \phi=$ soil production rate $\left[\mathrm{t} / \mathrm{m}^{2} / \mathrm{T}\right], q_{\mathrm{e}}=$ soil erosion rate per unit area $\left[\mathrm{t} / \mathrm{m}^{2} / \mathrm{T}\right], q_{\mathrm{w}}=$ chemical weathering rate per unit area $\left[\mathrm{t} / \mathrm{m}^{2} / \mathrm{T}\right]$ (modified after Yoo et al. 2007; Yoo and Mudd 2008).

For sustainable land use, the following condition should be fulfilled (Fig. 4):

$F_{\text {soil }} \geq 0$
$P_{\text {soil }} \geq D_{\text {soil }}$

Denudation fluxes $(D)$ can be subdivided into physical erosion fluxes $(E)$ and chemical weathering fluxes $(W)$ with

$D_{\text {soil }}=E_{\text {soil }}+W_{\text {soil }}$
Several authors (Riebe et al. 2004a, b; West et al. 2005; Maurin et al. 2005; Larsen et al. 2014) showed the importance of physical erosion on denudation rates. Erosion can be calculated with the chemical depletion factor, CDF. This factor is defined as (Riebe et al. 2001, 2003, 2004a, b)

$\frac{W_{\text {soil }}}{D_{\text {soil }}}=\left(1-\frac{(\mathrm{Zr})_{\text {rock }}}{(\mathrm{Zr})_{\text {soil }}}\right)=\mathrm{CDF}$

where $(\mathrm{Zr})_{\text {rock }}$ is the concentration of zirconium $(\mathrm{Zr})$ in the rock or parent material and $(\mathrm{Zr})_{\text {soil }}$ the concentration of $\mathrm{Zr}$ in the soil. Zirconium and titanium (Ti) are considered to be among the most insoluble and weathering-inert elements having almost no output in the soil water (Chadwick et al. 1990; White 1995). Combining Eqs. (4) and (5) one obtains:

$E_{\text {soil }}=(1-\mathrm{CDF}) \cdot D_{\text {soil }}$

Most soils feature a maximum possible CDF of 0.5 to 0.1 (that finally depends on climate and parent material: Dixon and von Blanckenburg 2012; Larsen et al. 2014); consequently soil erosion accounts for at least half of the denudation.

Within the context of sustainable land use, tolerable values for erosion are urgently needed. Erosion (and, in general, denudation) should not exceed soil production. One major problem in deriving such tolerable values is that soil formation and soil production are not static quantities that can be derived directly from the analysis of a single soil profile. Soil 
formation is highly dynamic (as stated above). Egli et al. (2014) showed that soil formation rates (soil thickness and geochemical losses) in high-mountain areas (alpine climate; siliceous parent material) range from very low to extremely high values and exhibited a clear decreasing tendency with time. Very young (initial) soils have up to three to four orders of magnitude higher rates of soil formation than old soils $\left(10^{5}\right.$ to $10^{6}$ years). Consequently, the fact that (Fig. 4)

$$
\begin{aligned}
& F_{\text {soil }}=f(t) \\
& D_{\text {soil }}=f(t)
\end{aligned}
$$

has to be taken into account when deriving tolerable values for erosion rates.

Uncertainty in calculating soil production rates is created by the soil skeleton material ( $>2 \mathrm{~mm}$ fraction), or rather whether or not this fraction is considered as soil (Egli et al. 2014). Particles $>2 \mathrm{~mm}$ are usually considered as 'chemically inert' for plant growth, although they can very well be the source of nutrients such as $\mathrm{Ca}, \mathrm{Mg}$ and $\mathrm{K}$ (Ugolini et al. 2001). In alpine areas, the soil skeleton mostly consists of primary silicates; consequently, the soil production rates were calculated by subtracting the skeleton weight from the total soil mass (Egli et al. 2014).

To determine the effect of erosion rates on soil thickness and soil formation, published data from alpine, subalpine and temperate climate regions having silicate parent material were collected and connected to the soil-forming factor 'time' (Eq. 2).

When discussing soil formation (also soil development; see Shaw 1930; Jenny 1941; Phillips 1993; Minasny et al. 2008; Sommer et al. 2008; Egli et al. 2014) we have to consider that soil is an open system with additions and removals of materials to and from the profile, including translocation of material and transformation processes within the profile. A soil system is defined by material input and outputs and consequently can be described by differential equations. Soil thickness and soil formation directly reflect a net change in mass balance of the soil compartment.

Formation rates of alpine soils (Wind River Range, Wyoming, USA; European Alps and other alpine areas; references are given in Egli et al. 2014; new data sets are published in Egli et al. 2014) were calculated from published data using the chronosequence approach (Fig. 5) where information was available about soil thickness (by horizon), bulk density and skeleton content (the thickness of transition horizons such as BC, AC, etc., are counted half; see Sauer 2010). The considered sites (European Alps, Wind River Range (USA), China and southeastern Peru) have siliceous parent material (with only minor, if any, addictions of carbonates in the case of the Chinese sites). Soil formation rates are usually calculated as an average rate over the entire evolution of a profile. This derived rate includes rates that are related to young and also older evolutionary stages. In this study, however, we were additionally able to calculate actual soil formation rates (of soils with known age, cf. Egli et al. 2014, Fig. 5a). The derivation of the regression curve gives the instantaneous or actual soil formation rate (Fig. 5b). These rates can be plotted as a function of time (Fig. 5b, c).

\subsubsection{Soil erosion}

Physical soil erosion (E) is defined as detachment and transport of soil material, which is, in Alpine grasslands, mostly due to three processes: (i) shallow landslide activity which is a mass movement of soil volume; (ii) sheet erosion (due to Hortonian overland flow), which is a gradual detachment and transport of single soil grains and aggregates and (iii) livestock trails (Fig. 1). While landslides can be monitored via digital mapping from aerial photographs or remote sensing (Meusburger and Alewell 2008; Meusburger et al. 2010), the estimation of sheet erosion in Alpine terrain is a more complex task and prone to many errors. For arable sites in Switzerland a a)

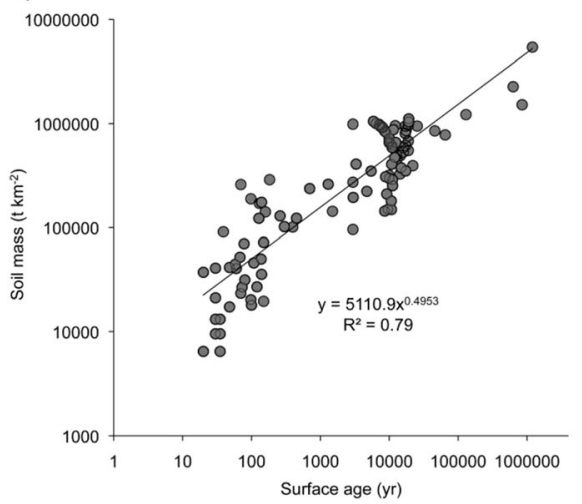

b)

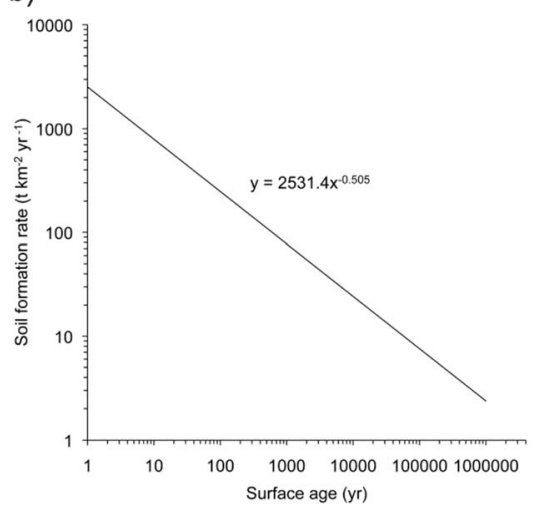

c)

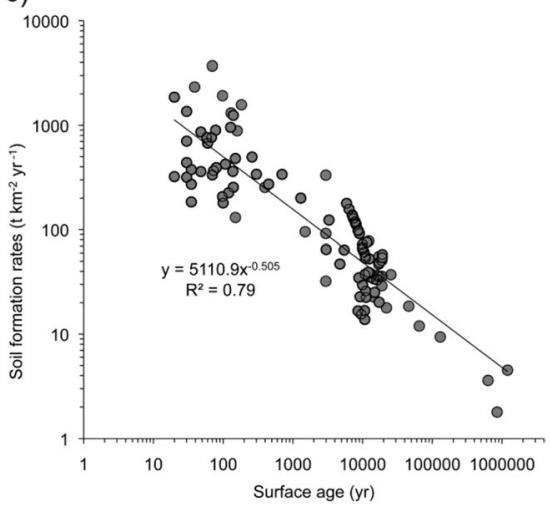

Fig. 5 a Produced soil mass in alpine soils as a function of time. Datasets are from the European Alps (Norton et al. 2010; Dahms et al. 2012, Egli et al. 2014), the Wind River Range (Rocky Mountains, USA; Dahms et al. 2012), China (He and Tang 2008), and southeastern Peru (Goodman et al. 2001). b Derivation of the regression function obtained from a. This derivation gives real-time formation rates (see also Eq. 2). c Integrated soil formation rates $\left(F_{\text {soil(I) }}\right)$ obtained from surface age and soil thickness and soil mass (rate $=$ Soil mass/surface age). Datasets are the same as in a 
detailed spatial soil erosion risk map based on the calculation using the Modified Universal Soil Loss Equation (MUSLE) is available (Gisler et al. 2010). For Alpine grasslands, however, neither guideline values of tolerable soil erosion rates nor a detailed comprehensive spatial mapping of actual soil erosion rates exist. Most critical is the regionalisation of vegetation covers, which is usually done by assigning uniform values from literature or field measured data to a classified land-cover map (Schwarz et al. 2004). This method results in constant and usually very low values of soil erosion for Alpine grasslands, and does not account for spatial or temporal variation in vegetation cover. Thus, a detailed soil erosion risk map has not been defined for Alpine grasslands yet. In the meantime, we have to use erosion estimates resulting from different methods of single case studies when evaluating the balance between soil formation and soil erosion. Methods vary from sediment trap measurements (Felix and Johannes 1995; Frankenberg et al. 1995; Langenscheidt 1995; Konz et al. 2012), the measurement of fallout radionuclides ${ }^{137} \mathrm{Cs}$ or ${ }^{239+240} \mathrm{Pu}$ (Meusburger et al. 2011; Alewell et al. 2013), modelling (Konz et al. 2010) or a combination of remote sensing and modelling (Meusburger et al. 2010).

In the approach we used, empirical erosion measurements of the Urseren valley were compared to soil formation and production rates (see section above). Recent soil erosion rates were determined in the case study Urseren Valley (Central Swiss Alps) at intensively used lower slopes using fallout radionuclides (FRN) averaging either the period since the 1960 s (using ${ }^{239+240} \mathrm{Pu}$ from atomic bomb fallout as isotopic tracer) or 1986 to today (using ${ }^{137} \mathrm{Cs}$ as fallout from the nuclear power plant accident in Chernobyl). Sampling details and analytical procedure are described in detail in Konz et al. (2009) and Alewell et al. (2013). It is important to note that FRN-based erosion rates cover all involved erosion processes over the given time span. In addition, using the Universal Soil Loss Equation (USLE), sheet erosion modelling was performed for the Urseren Valley that enabled the calculation of average erosion rates over the whole catchment area (Meusburger et al. 2010). Spatial resolution was defined by the digital elevation model having a grid of $25 \mathrm{~m}$. The USLE only considered sheet erosion due to rainfall erosivity and reduced vegetation cover. Landslides, livestock trails or winter processes such as avalanches and snow gliding are consequently not implemented in the model. As such, USLE-based erosion rates can be considered to be rather conservative estimates for Alpine catchments.

The measured and modelled erosion rates were then compared to soil formation and production rates of subalpine to alpine soils that have developed on silicate (granitic) parent material. A compilation of datasets about soil production and formation was performed for sites where surface age or the age of the soils was known.

\subsection{Error estimation and statistics}

Soil formation and production rates were estimated using our own and literature data and then compared to erosion rates. Average values (and standard deviation) of these factors were calculated for a given time range: very young soils $(\leq 1 \mathrm{kyr})$, young and shallow soils ( $>1-10 \mathrm{kyr})$ and older soils $(>10$ $18 \mathrm{kyr})$. These age ranges are typical for Alpine soils. As soil production $\left(P_{\text {soil }}\right)$ is the sum of soil formation $\left(F_{\text {soil }}\right)$ and denudation $\left(D_{\text {soil }}\right.$; see Eq. 4$)$, the corresponding error propagation was calculated as follows (for simplicity, $F_{\text {soil }}=x$ and $D_{\text {soil }}=y$ ):

$$
\begin{gathered}
\sigma_{x, y}=\frac{1}{N} \sum_{i=1}^{N}\left(x_{i}-\mu_{x}\right)\left(y_{i}-\mu_{y}\right) \text { and } P_{\text {soil }}=F_{\text {soil }}+D_{\text {soil }}=x+y \\
\sigma_{P_{\text {soil }}}=\sqrt{\sigma_{x}^{2}\left(\frac{\partial P_{\text {soil }}}{\partial x}\right)_{\mu_{x}}+\sigma_{y}^{2}\left(\frac{\partial P_{\text {soil }}}{\partial y}\right)_{\mu_{y}}+2\left(\frac{\partial P_{\text {soil }}}{\partial x}\right)_{\mu_{x}}\left(\frac{\partial P_{\text {soil }}}{\partial y}\right)_{\mu_{y}} \sigma_{x, y}}
\end{gathered}
$$

Due to the fact that for a specific site often not all the information is available (erosion rates, soil formation rates, soil production rates), the calculation of tolerable erosion is not straightforward.

The individual data sets were checked for normal distribution using a Shapiro-Wilk test (using a two-tailed test for significance; SigmaPlot 11.0 (Systat Software Inc.); Jann (2005)). The age-grouped data were often close to a normal distribution, whereas the whole data sets (not subdivided into age-classes) showed in most cases a lognormal distribution.

\section{Results and discussion}

4.1 Measurement and modelling of physical soil erosion (E) in Alpine grasslands

The focus in past erosion research in the Alps has almost entirely been on point measurements (so called plot studies), lumped measurements of hydrographs and sedigraphs at the outlet of the catchment and/or on sprinkling experiments. These measurements showed that an intact vegetation cover prevents soil loss (Felix and Johannes 1995; Frankenberg et al. 1995; Langenscheidt 1995-measurements on grazed pastures having sediment traps). However, on intensively grazed grassland plots with clear signs of degradation (reduced vegetation cover) a mean erosion rate of $2,000 \mathrm{t} \mathrm{km}^{-2}$ year $^{-1}$ (during a 6-year measurement period) could be observed that approximates a profile loss of $3 \mathrm{~mm}$ 
per year (Frankenberg et al. 1995; Table 1). The plots of Frankenberg et al. (1995) were located on parent material of Flysch and Molasse in the Allgäuer Alps. In the Bavarian Alps (Kalkalpine), Felix and Johannes (1995) determined erosion rates of $440 \mathrm{t} \mathrm{km}^{-2}$ year $^{-1}$ (during a 2-year measurement period) for a grassland test plot having a fractional vegetation cover of $66 \%$ due to pasturing. In another region of the Bavarian Alps, Ammer et al. (1995) measured soil erosion rates of approximately $200-900 \mathrm{t} \mathrm{km}^{-2}$ year ${ }^{-1}$ (during a 5-year measurement period) after clear-cutting of a small forested catchment, which geologically belongs to the Flysch and Kalkalpine formations. A review on erosion measurements on marls in the French Alps resulted in erosion rates of 1,400$3,300 \mathrm{t} \mathrm{km}^{-2}$ year $^{-1}$ (Descroix et al. 2003). In the northern French Alps, sediment deposits of 0.6 to $1.8 \mathrm{~cm}$ were observed during single events depending on the vegetation type and fractional vegetation cover (Isselin-Nondedeu and Bedecarrats 2007).

Recent soil erosion rates determined in the case study Urseren Valley (Central Swiss Alps) at affected sites of the intensively used lower slopes using fallout radionuclides (FRN) were up to $1,400 \mathrm{t} \mathrm{km}^{-2}$ year ${ }^{-1}$ (averaging the period from 1960 to today in using ${ }^{239+240} \mathrm{Pu}$ as tracer, Alewell et al. 2013) and even up to $3,000 \mathrm{t} \mathrm{km}^{-2}$ year ${ }^{-1}$ (averaging the period 1986 to today using ${ }^{137} \mathrm{Cs}$ as a tracer, Konz et al. 2009). Modelled values of sheet erosion for the Urseren Valley integrating the whole catchment using the USLE were reported to be approximately $118 \mathrm{t} \mathrm{km}^{-2}$ year $^{-1}$ (Table 1 ; Meusburger et al. 2010) plus soil loss due to landslide activity of $60 \mathrm{t} \mathrm{km}^{-2}$ year $^{-1}$ (Table 1; Meusburger and Alewell 2008). The large differences between the FRN measurements and the results of USLE modelling can be explained by the following: (i) FRN measurements focused on heavily-degraded grassland slopes - the aim was to determine erosion of strongly affected sites (Konz et al. 2009; Alewell et al. 2013); (ii) the USLE reproduced a modelled average for the catchment (please note that streams, settlements, bare rock and glaciers were excluded from the calculations; Meusburger et al. 2010) and (iii) the USLE does not include winter processes (e.g. soil erosion due to avalanches, snow gliding or snow ablation) or livestock trails. As a consequence, USLE gives rather conservative estimates of soil erosion potential for alpine regions during the vegetation period.

\subsection{Soil formation and production in Alpine grasslands}

Soil formation rates that were assessed in this study are consistent with the larger-scale reports (Table 1; Yoo and Mudd 2008; Norton et al. 2010; Dosseto et al. 2011).

According to Eq. (1), soil formation rates only estimate the net effects. In the case of stable sites with almost no denudation, we have $F_{\text {soil }} \approx P_{\text {soil. }}$. Total denudation $\left(D_{\text {soil }}\right)$ can be estimated using terrestrial cosmogenic nuclides. $D_{\text {soil }}$ values for alpine and subalpine regions, where a temporal assignment

Table 1 Long-term soil formation and production rates compared to recent soil erosion rates reported for Alpine sites. Conversions from $\mathrm{t} \mathrm{km}^{2} \mathrm{year}^{-1}$ to $\mathrm{mm}$ year ${ }^{-1}$ and vice versa where calculated using a soil bulk densities of $1 \mathrm{t} \mathrm{m}^{-3}$ (surface horizon) when no other values were given in the cited literature

$\begin{array}{lll}\begin{array}{l}\text { Rate } \\ \mathrm{t} \mathrm{km}^{-2} \text { year }^{-1}\end{array} & \begin{array}{l}\text { Rate } \\ \text { mm year }\end{array} & \text { Specifications }\end{array}$

\begin{tabular}{|c|c|c|c|}
\hline Alpine sites (Table 2, Figs. 5 and 6) & 54 up to $>1,000$ & 0.040 up to $>0.75$ & Soil production \\
\hline (average values) & 20 up to $>1,000$ & 0.015 up to $>0.75$ & Soil formation \\
\hline Norton et al. (2010) & $39-178$ & $0.022-0.099$ & Soil production, Swiss Central Alps \\
\hline \multicolumn{4}{|l|}{ (B) Soil degradation } \\
\hline \multicolumn{4}{|l|}{ (B1) Own data from Alpine sites } \\
\hline Konz et al. (2010), Alewell et al. (2014) & $1400-3000 \mathrm{a}$ & $1.4-3.0$ & Strongly affected sites, Urseren Valley \\
\hline Meusburger and Alewell (2009) & $60 \mathrm{a}$ & 0.06 & Landslides Urseren Valley \\
\hline Meusburger et al. (2010) & $118 \mathrm{a}$ & 0.118 & Sheet erosion Urseren Valley \\
\hline Meusburger et al. $(2009,2010)$ & $178 \mathrm{a}$ & 0.178 & Landslides plus sheet erosion \\
\hline \multicolumn{4}{|l|}{ (B2) Literature data } \\
\hline \multirow[t]{2}{*}{ Dosseto et al. (2011) } & 400 & $0.400 \mathrm{~b}$ & Lower range for Alps \\
\hline & 20,000 & $20 \mathrm{~b}$ & Higher range for Alps \\
\hline Felix and Johannes (1995) & $440 \mathrm{a}$ & 0.44 & Calcareous Alps, Bavaria \\
\hline Frankenberg et al. (1995) & $3,000 \mathrm{a}$ & $3 b$ & Flysch, Molasse, Allgäuer Alps \\
\hline Ammer et al. (1995) & $200-900 a$ & $0.2-0.9$ & Flysch, calcareous Alps \\
\hline Descroix et al. (2003) & $1,400-3,300 \mathrm{a}$ & $1.4-3.3$ & French Alps \\
\hline Isselin-Nondedeu and Bedecarrats (2007) & $6,000-18,000$ & $6-18 b$ & Heavy rain events, French Alps \\
\hline
\end{tabular}

$a, b$ gives the original published number which was converted $\left(\mathrm{t} \mathrm{km}^{-2}\right.$ year $^{-1}$ versus $\left.\mathrm{mm} \mathrm{year}^{-1}\right)$ 
was possible (Norton et al. 2010; Dixon et al. 2009; Heimsath et al. 2001), are plotted in Fig. 6 and are parallel to those of $F_{\text {soil }}$ (Fig. 6a, c) when plotted over time. Soil production can now be calculated by summing up the soil formation $\left(F_{\text {soil }}\right)$ and denudation rates $\left(D_{\text {soil }}\right)$. One major problem in this case is that the denudation rates were not measured at the same sites where the soil formation rates were determined. Nonetheless, it is a first attempt and the order of magnitude of the values should be correct. Soil formation and production considerably vary over time and are in the range of only a few (for very old soils) to more than $1,000 \mathrm{t} \mathrm{km}^{-2}$ year ${ }^{-1}$.

a)

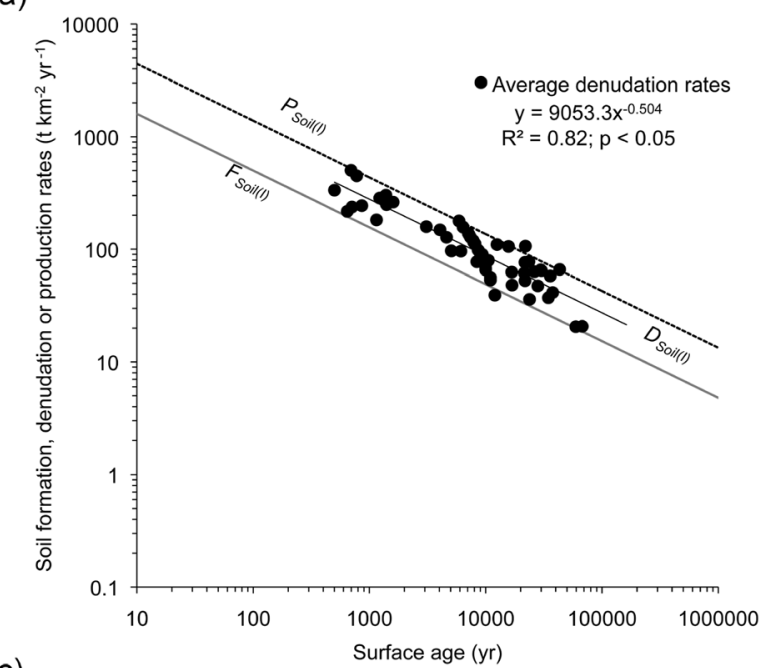

c)

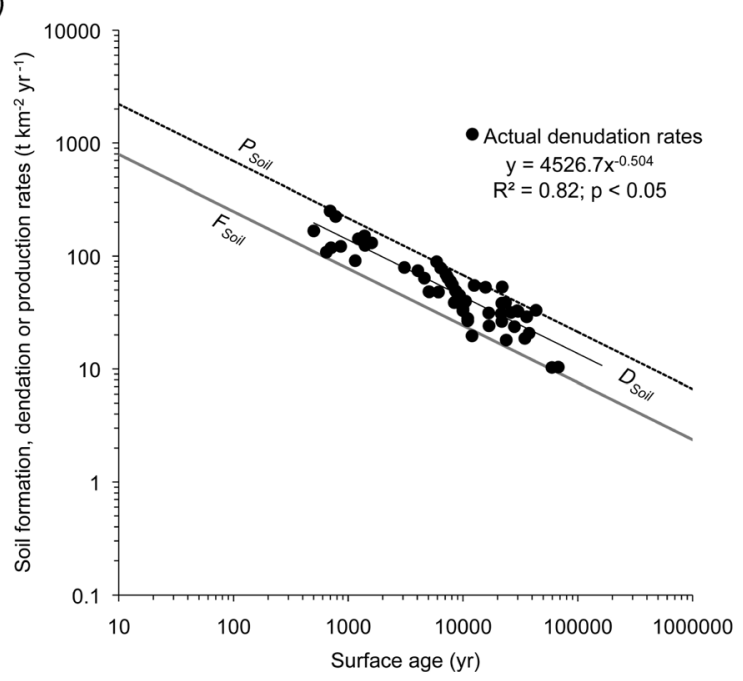

Fig. 6 Calculation of soil production and tolerable erosion rates using two approaches ( $\mathrm{a}, \mathrm{b}$ vs $\mathrm{c}, \mathrm{d})$ to delineate minimum and maximum values. a Estimation of soil production rates $\left(P_{\text {soil(I) }}\right)$ using soil formation rates $\left(F_{\text {soil(I) }}\right)$ obtained from Fig. 5 and total denudation rates $\left(D_{\text {soil(I) }} ;\right.$ Eq. 4$)$ of alpine soils (black dots: data from Norton et al. 2010; Dixon et al. 2009; Heimsath et al. 2001). $P_{\text {soil }}=F_{\text {soil }}+D_{\text {soil }}$ (dashed line; see Eq. 1). $I$ stands for an integrated (average) rate over the whole time period considered (e.g. produced soil mass or denudation divided by the surface age); b Erosion rates ( $E$; Eq. 5 and 6 ) related to soil depth (calculated by dividing $P_{\text {soil(I) }}$ by soil density $\left(1.2 \mathrm{t} / \mathrm{m}^{3}\right.$; an average value considering top- and
Soil mass is a function of the development stage of a soil and consequently its age. It can be transformed into a corresponding soil depth $\left(z_{w}\right)$ according to:

$M_{\text {soil }}(t)=\sum_{t=0}^{n}\left(P_{\text {soil }}-E_{\text {soil }}-W_{\text {soil }}\right) \Delta t$

$z_{w}(t)=M_{\text {soil }}(t) / \rho_{w}$

with $P_{\text {soil }}, E_{\text {soil }}$ and $W_{\text {soil }}$ as soil production, erosion and weathering rates, respectively and $\rho_{w}$ as bulk density.

b)

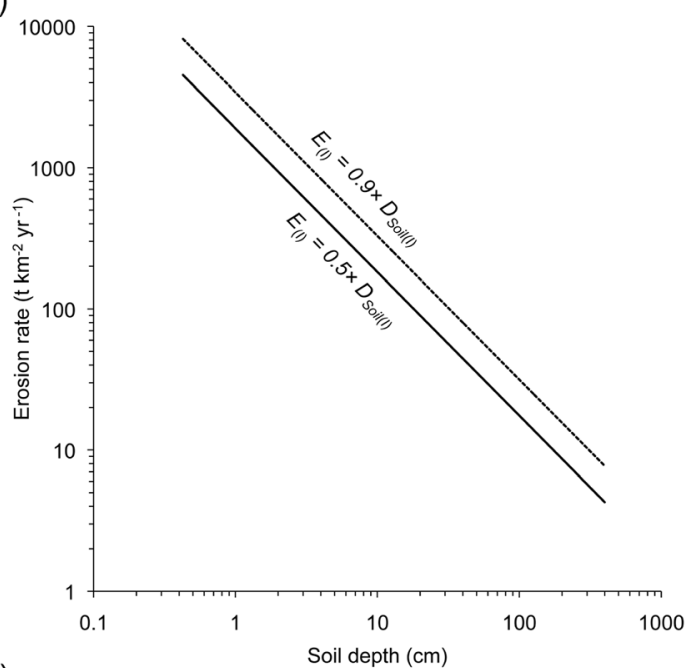

d)

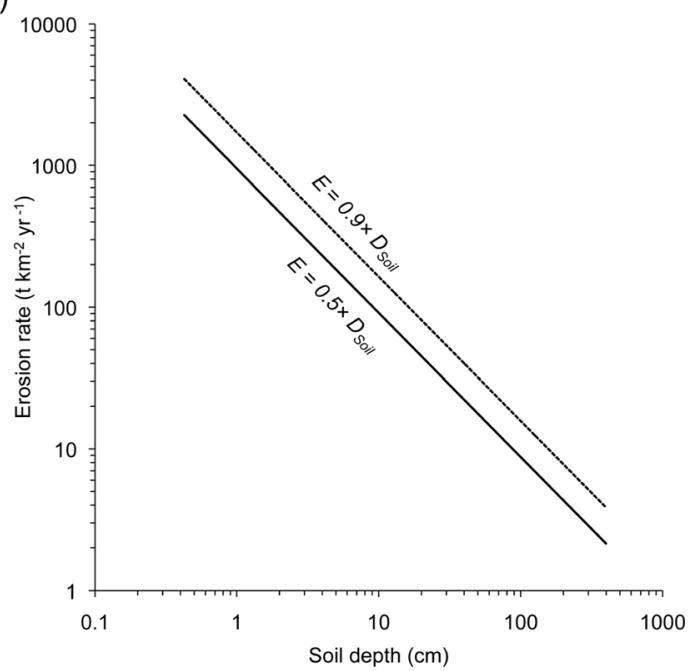

subsoil material) assuming that $E$ is in the range of $0.5-0.9 \times D$ (Dixon and von Blanckenburg 2012). Dashed line: $E=0.9 \times D$. Note: $P_{\text {soil }}$ is the amount of produced fine earth $(<2 \mathrm{~mm}$ in diameter), $\mathbf{c}$ Estimation of soil production rates $\left(P_{\text {soil }}\right)$ using soil formation rates $\left(F_{\text {soil }}\right)$ obtained from Fig. 5 (actual rates) and total denudation rates of alpine soils (data from Norton et al. 2010; Dixon et al. 2009; Heimsath et al. 2001); to obtain the instantaneous or actual rates, the values were divided by 2 (Fig. $5 \mathrm{~b}$, c; see text for explanations). $P_{\text {soil }}=F_{\text {soil }}+D_{\text {soil }}$ (dashed line). $\mathbf{d}$ Erosion rates $(E)$ related to $P_{\text {soil }}$ as calculated in $\mathbf{c}$, assuming that $\mathrm{E}$ is in the range of $0.5-$ $0.9 \times D$ (Dixon and von Blanckenburg 2012). Dashed line: $E=0.9 \times D$ 
According to Eq. 4, the total denudation rate $D_{\text {soil }}$ is the sum of erosion and weathering rate. Dixon and von Blanckenburg (2012) demonstrate that soil erosion (catchment-wide to profile related data) is in the range of $0.5-0.9 D_{\text {soil }}$.

$0.5 \cdot D_{\text {soil }} \leq E_{\text {soil }} \leq 0.9 \cdot D_{\text {soil }}$

Knowing $M_{\text {soil }}(t), P_{\text {soil }}(t)$ and $D_{\text {soil }}(t)$, then $E_{\text {soil }}$ as a function of time can be derived. Because $M_{\text {soil }}=f(t)$ it follows that $z_{w}=f(t)$. From this, we can derive that $E_{\text {soil }}=f\left(z_{w}\right)$.

Using now the soil mass as a function of time and combining it together with the density of the fine material (approx. $1.2 \mathrm{~g} \mathrm{~cm}^{-3}$ as a mean value of the whole profile) then the connected erosion rate as a function of profile thickness (soil depth) can then be plotted. The diagram (Fig. 6b, d) enables the approximate prediction of profile thickness towards which a soil would tend having a given erosion rate. An erosion rate of $50 \mathrm{t} \mathrm{km}^{-2}$ year $^{-1}$ would lead (in the long-term) to a soil having an overall depth of 20 to a maximum of $60 \mathrm{~cm}$ depth (only fine earth). Taking a skeleton of 50 mass-content- $\%$ into account, then additional 30 to $50 \mathrm{~cm}$ of soil thickness can be added.

Assuming that all parameters (soil formation, soil production, total denudation) show a log-normal distribution for the individual and age-grouped datasets then the following questions can be addressed: (i) what is the theoretical likelihood that soil production and denudation are currently equal (for individual age groups)? and (ii) what is the theoretical likelihood that soils are indeed being eroded faster than they are being produced (for different age groups)?

Taking the values given in Table 2 (and average values over the given time sequence) then typical soil production values for very young, young and old soils are 881, 248 and
$113 \mathrm{t} \mathrm{km}^{-2}$ year $^{-1}$, respectively. To answer the first question, a suitable range has to be taken into account in which denudation and production rates are assumed to be more or less equal. This range is set to $50 \mathrm{t} \mathrm{km}^{-2}$ year $^{-1}$ (for all classes). Under such assumptions, the probability (by taking the probability density functions into account) that we have more or less equal soil production and denudation rates increases with age from $1.2 \%$ (very young soils, $\leq 1 \mathrm{kyr}$ ), to $5.1 \%$ (young soils; >1-10 kyr) and $8.7 \%$ (old soils; > 10-18 kyr). The numbers might be somewhat arbitrary but the general trend definitely makes sense. The older the surface and soils, the closer one gets to an equilibrium and finally the lower is the soil formation (as a net effect between soil production and denudation; see Fig. 5). There is consequently a certain probability that Alpine soils, having an age of 10-18 kyr, are (under natural conditions) close to an equilibrium. This finding fits well with Norton et al. (2010) who found that Alpine soil production and erosion have continued sufficiently long to be close to a quasi-steady state after about $15 \mathrm{kyr}$. To answer the second question aiming to determine the probability of soil erosion being higher than soil production, we have to consider that $E_{\text {soil }}=0.5-0.9 D_{\text {soil }}$ and that $F_{\text {soil }} \leq 0$. Under such conditions, $0.5-0.9 P_{\text {soil }}$ will be $\leq E_{\text {soil }}$. This enables a rough estimate to be made using the probability density functions and taking the standard deviation of soil production and erosion rates of the individual groups into account. Again, the probability increases with soil age that total denudation (of which 50 to $90 \%$ can be attributed to erosion) exceeds soil production. For very young soils, this probability would be approximately in the range of $12-26 \%$ and for old soils in the range of $21-$ $36 \%$. This shows that old surfaces have a higher risk of a retrograde soil evolution (where erosion or denudation is $>$ soil

Table 2 Average soil formation $\left(F_{\text {soil }}\right)$, denudation $\left(D_{\text {soil }}\right)$, production $\left(P_{\text {soil }}\right)$ and erosion $\left(E_{\text {soil }}\right)$ rates (data origin cf. Figs. 5 and 6$)$ as a function of soil age range (very young soils: $\leq 1 \mathrm{kyr}$; young and shallow soils $>1-10 \mathrm{kyr}$; older soils: $>10-18 \mathrm{kyr}$ ) and calculation scenario

\begin{tabular}{|c|c|c|c|c|c|c|}
\hline & $\begin{array}{l}\leq 1 \mathrm{kyr} \\
\mathrm{t} \mathrm{km}^{-2} \text { year }^{-1}\end{array}$ & $\begin{array}{l}\text { SD } \\
\text { t km }^{-2} \text { year }^{-1}\end{array}$ & $\begin{array}{l}>1-10 \mathrm{kyr} \\
\mathrm{t} \mathrm{km}^{-2} \text { year }^{-1}\end{array}$ & $\begin{array}{l}\text { SD } \\
\text { t km }^{-2} \text { year }^{-1}\end{array}$ & $\begin{array}{l}>10-18 \mathrm{kyr} \\
\mathrm{t} \mathrm{km}^{-2} \text { year }^{-1}\end{array}$ & $\begin{array}{l}\text { SD } \\
\text { t km }^{-2} \text { year }^{-1}\end{array}$ \\
\hline$F_{\text {soil }}(\mathrm{I})$ & 550 & 390 & 99 & 52 & 45 & 20 \\
\hline$D_{\text {soil }}(\mathrm{I})$ & 331 & 121 & 149 & 64 & 68 & 22 \\
\hline$P_{\text {soil }}(\mathrm{I})$ & 881 & 520 & 248 & 91 & 113 & 30 \\
\hline$F_{\text {soil }}(\mathrm{II})$ & 250 & 177 & 45 & 24 & 20 & 9 \\
\hline$D_{\text {soil }}$ (II) & 165 & 60 & 74 & 32 & 34 & 11 \\
\hline$P_{\text {soil }}(\mathrm{II})$ & 415 & 242 & 119 & 44 & 54 & 14 \\
\hline \multicolumn{7}{|l|}{$(\mathrm{I})^{\mathrm{a}}$} \\
\hline$E_{\text {soil }}=0.5 \times D_{\text {soil }}$ & 165 & 60 & 74 & 32 & 34 & 11 \\
\hline$E_{\text {soil }}=0.9 \times D_{\text {soil }}$ & 298 & 109 & 134 & 58 & 61 & 20 \\
\hline \multicolumn{7}{|l|}{ (II) $)^{\mathrm{a}}$} \\
\hline$E_{\text {soil }}=0.5 \times D_{\text {soil }}$ & 83 & 30 & 37 & 16 & 17 & 5 \\
\hline$E_{\text {soil }}=0.9 \times D_{\text {soil }}$ & 149 & 54 & 67 & 29 & 30 & 10 \\
\hline
\end{tabular}

I: using integrated rates (average value over a given time sequence), II using real-time rates (cf. Eq. 2)

${ }^{\mathrm{a}}$ Eq. 11 
production) caused by human impact, because soil production has distinctly slowed down.

\subsection{Tolerable soil erosion rates}

To develop a concept of sustainable land use in alpine areas, tolerable soil erosion rates have to be defined as guidelines that do not exceed soil formation rates. This is not an easy task as soil formation or production and erosion rates often show considerable variability. Independent of the methodology used to determine soil formation or soil production rates $\left({ }^{10} \mathrm{Be}\right.$, ${ }^{26} \mathrm{Al},{ }^{230} \mathrm{Th} /{ }^{234} \mathrm{U}$ activity ratios or soil chronosequence approach), a distinct variability exists even among the same ecosystems (Egli et al. 2014; cf also Figs. 5 and 6).

Two concepts are presented:

Concept 1 Soil production is a strong function of time. Average soil production of relatively old soils $(>10-18 \mathrm{kyr})$ is between $54( \pm 14)$ and $113( \pm 30)$ $\mathrm{t} \mathrm{km}^{-2}$ year ${ }^{-1}$, of young shallow soils $(>1-$ 10 kyr) between $119( \pm 44)$ and $248( \pm 91)$ $\mathrm{t} \mathrm{km}^{-2}$ year ${ }^{-1}$ and of very young soils $(\leq 1 \mathrm{kyr})$ between $415( \pm 242)$ and $881( \pm 520)$ $\mathrm{t} \mathrm{km}^{-2}$ year $^{-1}$ (Table 2). Due to the fast glacier retreat after the Late Glacial Maximum (LGM), the surface age of most areas (having meadows) in the subalpine to the alpine range of the European Alps is near 10 to $18 \mathrm{kyr}$ (Ivy-Ochs et al. 2004). At such sites (having a surface age of $>10$ to $18 \mathrm{kyr}$ ) and under undisturbed conditions, soil production rates would be in the range of $54( \pm 14)$ to $113( \pm 30) \mathrm{t} \mathrm{km}^{-2}$ year $^{-1}$ (Figs. 6a, c; Table 2) and soil formation in the range of $20( \pm 9)$ to $45( \pm 20) \mathrm{t} \mathrm{km}^{-2}$ year (Fig. 5c; Table 2). To prevent soil degradation, today's erosion rates consequently should not exceed soil production - under the strongly simplified assumption that $E \approx D$ and $W \approx 0$, we obtain a maximum tolerable value for erosion; Eq. 4. If, however, we consider that $E$ is approx. 0.5 to $0.9 D$ then the derived values for a tolerable erosion rate would be even lower (by 10 to $50 \%$ ). This gives a first possibility of defining tolerable maximum values for soil erosion. These values $\left(54-113 \mathrm{t} \mathrm{km}^{-2}\right.$ year $^{-1}$ or 50 to $90 \%$ of it: $27-102 \mathrm{t} \mathrm{km}^{-2}$ year $^{-1}$ ) are astonishingly close to those estimated by Verheijen et al. (2009) for European soils (that have in most cases an age of $>10 \mathrm{kyr}$ ). Verheijen et al. (2009) concluded that the upper limit of tolerable soil erosion is c. $140 \mathrm{t} \mathrm{km}^{-2}$ year ${ }^{-1}$ while the lower limit is c. $30 \mathrm{t} \mathrm{km}^{-2}$ year $^{-1}$ for conditions prevalent in Europe.
Concept 2 Erosion rates can be connected to a resulting soil depth (Fig. 6b, d). If a soil thickness of $20 \mathrm{~cm}$ (only fine earth=fraction $<2 \mathrm{~mm}$; see Fig. 6) is considered to be sustainable (in the long-term) then erosion should not exceed 90 $110 \mathrm{t} \mathrm{km}^{-2}$ year $^{-1}$ when time-averaged rates are considered and $45-80 \mathrm{t} \mathrm{km}^{-2}$ year ${ }^{-1}$ when the actual rates are used. The ranges are due to the fact that $E_{\text {soil }}=0.5-0.9 D_{\text {soil }}$. Using the upper and lower limits of these ranges, we can roughly estimate that the erosion rates should not exceed 45 to $110 \mathrm{t} \mathrm{km}^{-2}$ year ${ }^{-1}$. A real Alpine soil not only consists of fine earth. The skeleton proportion very often exceeds $50 \%$. Consequently, soils would be at least twice as thick $(\geq 40 \mathrm{~cm})$ if the rock fragments are considered.

4.4 Soil sediment budgets indicate unsustainable management

Modelled values of sheet erosion for the Urseren Valley averaged over the whole catchment were reported to be approximately $118 \mathrm{t} \mathrm{km}^{-2}$ year $^{-1}$ (Meusburger et al. 2010) and soil loss due to landslide activity to be $60 \mathrm{t} \mathrm{km}^{-2}$ year $^{-1}$ (Meusburger and Alewell 2008)_both processes summing up to $178 \mathrm{t} \mathrm{km}^{-2}$ year ${ }^{-1}$. Thus, the current site management in the Urseren Valley must be considered unsustainable from an ecological perspective due to its exceeding the sensitive balance between natural average long-term soil production and erosion. Actual recent soil erosion rates (average $178 \mathrm{t} \mathrm{km}^{-2}$ year $^{-1}$ and at strongly affected sites up to 1,400 or even 3,000 t km${ }^{-2}$ year $^{-1}$; Table 1) are significantly higher than the corresponding soil production rates for soils having an age of 10-18 kyr.

Assuming the Alpine valleys to have been ice-free for the last 15,000 years (after the last glaciation) and using a timeintegrated average soil formation rate of $0.06 \mathrm{~mm}_{\text {year }}{ }^{-1}$ for the Central Swiss Alps (e.g. Norton et al. 2010, Table 1), the average soil depth (fine earth and skeleton) in the valley would have been around $90 \mathrm{~cm}$ when human settlement began. Deforestation was the start of continuous soil erosion approximately 1,000 years ago and if we assume today's average erosion rates of $0.18 \mathrm{~mm}^{\text {year }}{ }^{-1}$, approximately $18 \mathrm{~cm}$ (assuming a bulk density of $1 \mathrm{t} \mathrm{m}^{-3}$ for surface horizons) of soil would have been lost by today (assuming that chemical weathering is negligible compared to soil erosion), which is a fifth of the whole soil profile. Although this calculation is very approximate, it points to a serious problem: a sizeable part of the original fertile soil has been lost. These average erosion rates would theoretically allow further land use for a maximum of 3,000 years. By then, the soil would have been completely eroded to a depth of less than $20 \mathrm{~cm}$, which might be considered the needed minimum depth for cattle grazing. 
However, in assessing erosion rates, average values are misleading. Erosion varies in time and space. Spatially averaged erosion rates integrate erosion over the whole catchment, including all grassland, forests, shrub land and wetlands. Forests, shrublands and wetlands usually have considerably lower erosion rates than the more intensively managed grasslands. As it has been shown by Frankenberg et al. (1995), Descroix et al. (2003), Konz et al. (2012) and Alewell et al. (2013), intensively used areas in the Alps might have considerably higher erosion rates than the average values of the whole catchment of the Urseren Valley. At strongly affected sites, erosion rates are estimated to be between 1.4 to $3 \mathrm{~mm}_{\text {year }}{ }^{-1}$ which would result in a total erosion depth of 1.4 to $3 \mathrm{~m}$ at such slopes during the last 1,000 years when human impact was considerable (settlement and deforestation). Anderson et al. (2007) showed that increasing erosion rates also cause an increase in chemical weathering. However, the latter is only valid to a certain break point (see Dixon and von Blanckenburg 2012) that corresponds to the weathering speed limit. However, this speed limit is still under discussion (Egli et al. 2014; Larsen et al 2014; Heimsath 2014). With such high erosion rates, soils would be completely removed in the long-term.

With respect to landslide activity, between 1959 and 2004, almost a doubling of the degraded area can be observed in the Urseren Valley (Meusburger and Alewell 2008; cf. Fig. 7). We cannot pin down the time point of the actual change from sustainable to unsustainable management from the data, because the earliest air photographs were only available from 1959 in which the soil degradation was already clearly shown. Since then, the eroded area affected by landslide activity has increased steadily (Fig. 8). A strong increase in landslide activity can be detected in the late 1970s and then again in the late 1990s (Fig. 8). The spatial pattern of soil degradation due to landslide activity in the Urseren Valley suggests an effect that is mostly due to changes in land-use practice and not to climate change: uncontrolled grazing since the late $70 \mathrm{~s}$ in the Urseren Valley gave rise to a concentration of cattle on the geologically more instable lower slopes during the whole vegetation period - this in contrast to before 1970 when cattle were herded at high alpine meadows during the summer (cf. Meusburger and Alewell 2008, 2009 for a more detailed discussion). Consequently, the most obvious disturbances
Fig. 7 Time series of air photographs near the village Hospental in the Urseren Valley (Central Swiss Alps) demonstrating the increase in landslide affected area between 1959 and 2004
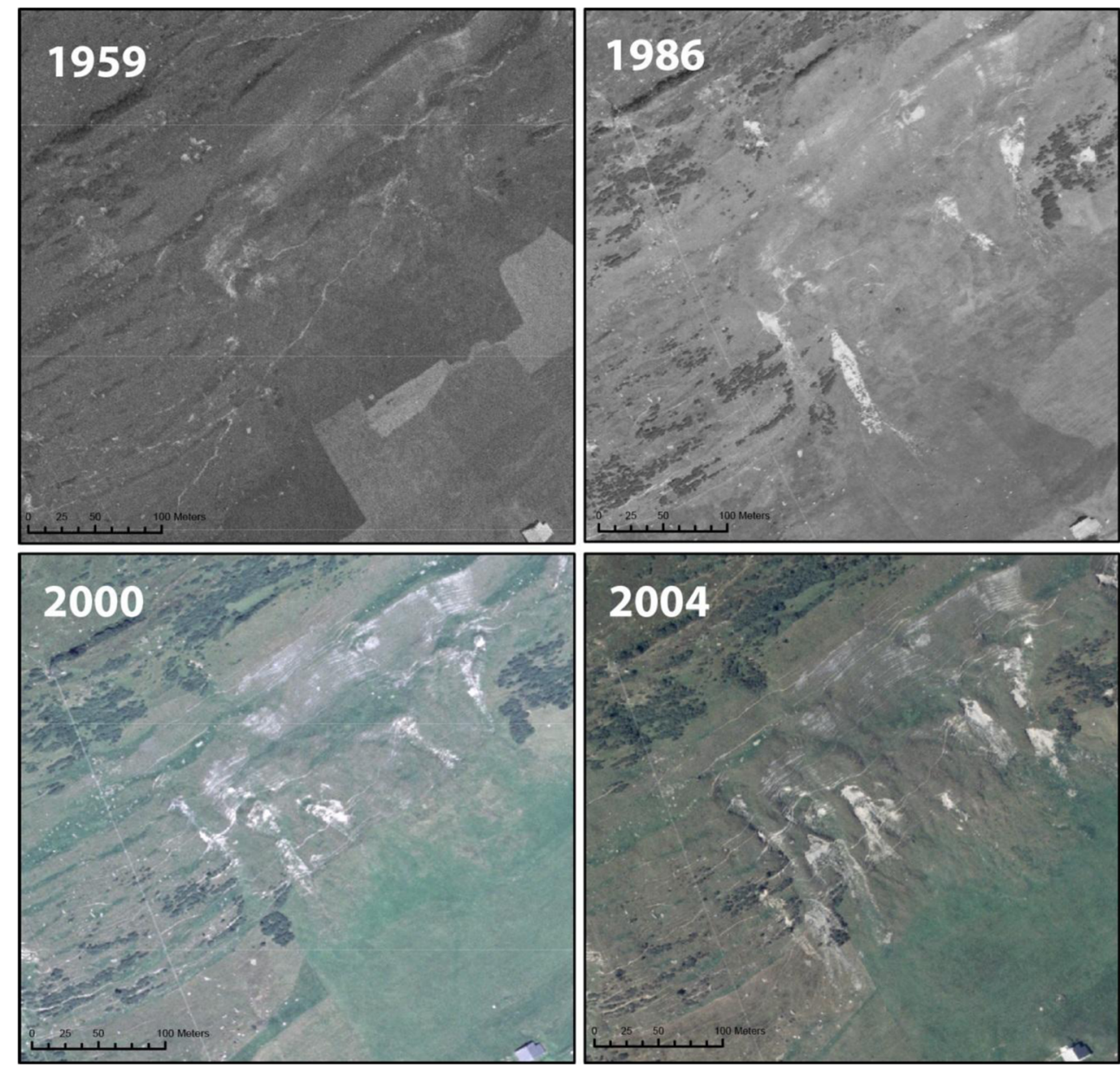
Fig. 8 Stocking densities of animals (left) and comparison between the increased landslide and stocking numbers (right) in the Urseren Valley
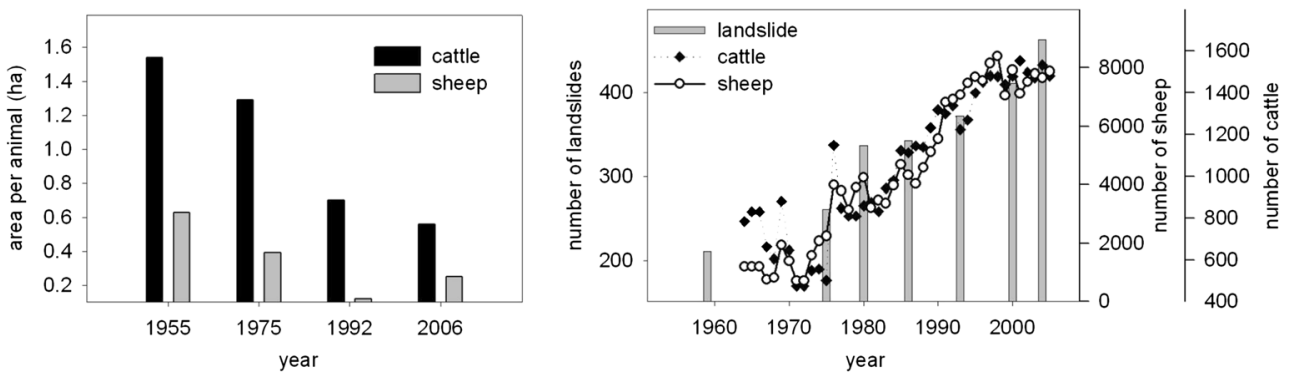

have occurred at relatively low-altitude pastures and not at the remote high-altitude sites.

No data over time exist for sheet erosion in the Urseren Valley which could indicate a change from sustainable to unsustainable land use. The only indication is a difference in erosion rates determined with two different methods: Konz et al. (2009) calculated erosion rates of up to $3,000 \mathrm{t} \mathrm{km}^{-2}$ year ${ }^{-1}$ based on the ${ }^{137} \mathrm{Cs}$ method which integrates erosion rates over the last 25 years (since the Chernobyl accident in 1986; the larger part of ${ }^{137} \mathrm{Cs}$ in the central Alps derives from this event). Alewell et al. (2013) delineated lower erosion rates having a maximum of $1,400 \mathrm{t} \mathrm{km}^{-2} \mathrm{year}^{-1}$ for the same sites when using the ${ }^{239+240} \mathrm{Pu}$ method, which integrates the last 50-60 years (plutonium originates from global nuclear weapons testing in the late 1950s and early 1960s). Thus, the comparison of these two datasets indicates an increase in soil erosion between the 1960s and the mid-1980s. However, both methods are connected to some uncertainties and limitations (Alewell et al. 2013; Mabit et al. 2013), and the differences between the two methods might not be related to the two considered time periods.

The soils in the Urseren valley are in the age range of $>10$ $18 \mathrm{kyr}$. The averaged erosion values $\left(178 \mathrm{t} \mathrm{km}^{-2}\right.$ year $\left.^{-1}\right)$ are already above the soil production rates of $54( \pm 14)$ and 113 $( \pm 30) \mathrm{t} \mathrm{km}^{-2}$ year $^{-1}$. Taking into account that $E_{\text {soil }}=0.5-$ $0.9 D_{\text {soil }}$, then the tolerable erosion rates should even be lower by $10-50 \%$ than the soil production rates (concept 1 ). An erosion rate of $178 \mathrm{t} \mathrm{km}^{-2}$ year $^{-1}$ would lead to a soil thickness (only fine earth) of about 6-20 cm (6-10 cm [actual rates] or $10-20 \mathrm{~cm}$ [averaged rates]). Assuming a skeleton content of $50 \%$ the resulting soils would be in the range of 12 to $40 \mathrm{~cm}$ - a low value, even for Alpine sites. At 'hot spots', erosion rates are from 1400 up to even $3000 \mathrm{t} \mathrm{km}^{-2}$ year ${ }^{-1}$. Thus, extremely shallow soils would be the consequence (an erosion rate of $1400 \mathrm{t} \mathrm{km}^{-2}$ year $^{-1}$ gives rise to a soil thickness in the range of 1 to $2 \mathrm{~cm}$ and $3000 \mathrm{t} \mathrm{km}^{-2}$ year $^{-1}$ to a soil thickness of $<1 \mathrm{~cm}$ ).

4.5 An attempt to assess future development of soil sediment budgets

Switzerland is one of the countries where strong climate change impacts are expected (Beniston 2006). Temperature increase is already clearly above the global average. Generally, the combined effects of climate and changing land use have been predicted to increase future soil erosion in Alpine regions (Frei et al. 2007). A rising snowline, intensified precipitation during the winter and strong leaching effects with no or sparse vegetation cover in late autumn and early spring could result in an increase in erosion especially in the Northern (mainly North-Western) Alps (Fuhrer et al. 2006; Scheurer et al. 2009). However, other models predict increased erosion susceptibility more on the southern part of the Alps (Bosco et al. 2009). Modelling results of sediment delivery to the river Rhine from Alpine regions indicated more than a $200 \%$ increase by the year 2100 (Asselman et al. 2003). In addition to changes in temperature and snow dynamics, an increase in torrential rain events has been monitored for the last three decades in the Urseren Valley (Fig. 9). Changes in snow dynamics and a higher frequency of torrential rain events are expected to increase soil erosion rates. As rainfall and vegetation cover are two main drivers of soil erosion by water, they are at the same time the parameters most likely to be affected by climate and changing land use. Thus, these two parameters are and will be of major concern to soil conservation; the temporal and spatial resolution of vegetation cover and rainfall effects will be crucial in the future.

Since 1989 rainfall erosivity significantly increased in the months of May to October in Switzerland (Meusburger et al. 2012). The added effect of high rainfall erosivity will most likely result in an increased soil erosion risk mainly in the months of May, September and October when vegetation cover is scarce in many regions (Meusburger et al. 2012).

In addition to changes connected to global climate change, European mountain systems have been experiencing a substantial change in land-use management during the last decades (Lasanta et al. 2006; Gellrich and Zimmermann 2007; Schneeberger et al. 2007). Since the late 19th century the abandonment of agricultural sites, especially in high alpine and remote areas is a well-known phenomenon (Swiss Federal Statistical Office 2001; Descroix and Mathys 2003; Piégay et al. 2004; Lasanta et al. 2006; Tasser et al. 2007). Simultaneously, the remaining farmland in lower areas having good accessibility has been utilised with increased intensity (Meusburger and Alewell 2008). In the Swiss Alps, the livestock population has increased from 200,000 to 420,000 sheep 
Fig. 9 Precipitation intensities as the 3-day sum $>100 \mathrm{~mm}$ in the Urseren Valley. Mann-Kendall trend test results in a significant increase $(p<0.05)$

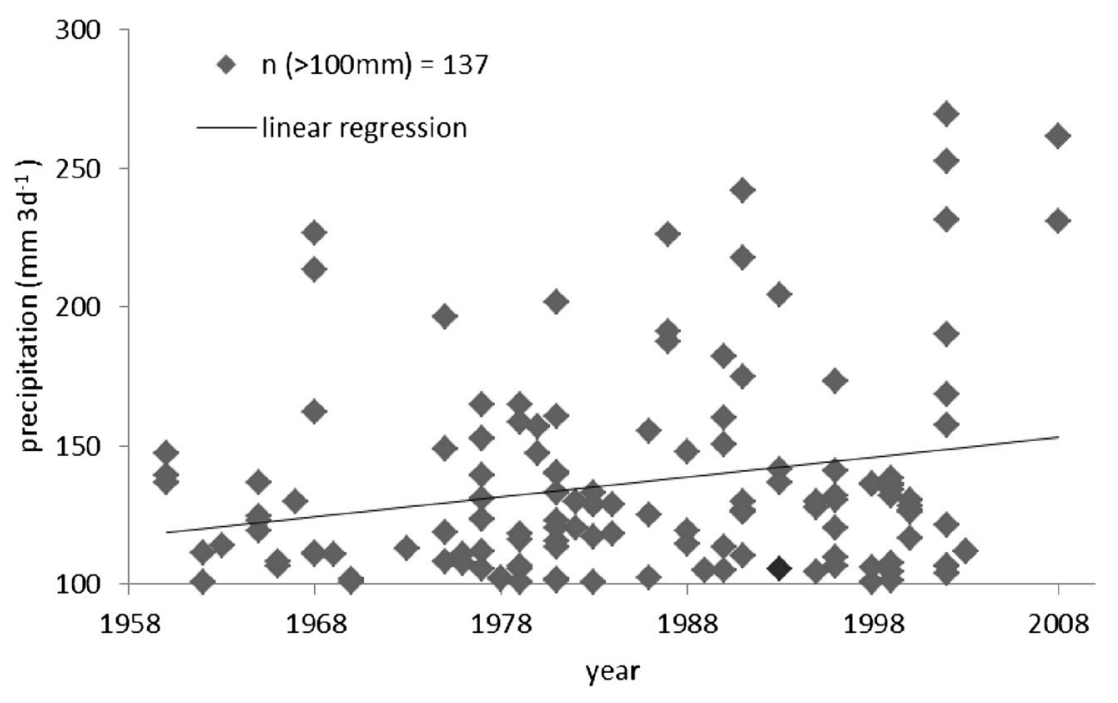

during the last 40 years (Troxler et al. 2004). The Urseren valley followed these regional trends and animal numbers increased significantly (Fig. 8). Furthermore, permanent shepherding of cattle and sheep has mostly been abandoned since 1950 and replaced by uncontrolled grazing. Uncontrolled grazing in the Urseren valley caused a concentration of cattle on the geologically more instable lower slopes during the whole vegetation period (Meusburger and Alewell 2008, 2009). Thus, destabilising effects on soils are closely connected to and affected by changes in animal farming practice.

Parallel and partly due to the above-described changes in grassland management, we observed an encroachment of shrubs in the Urseren valley (Fig. 10). Thus, even though animal numbers and grazing intensity increased considerably in some areas, we see shrub encroachment in other areas of the Urseren valley because the animals are not herded and maintenance of the sites decreased (Caviezel et al. 2010). This

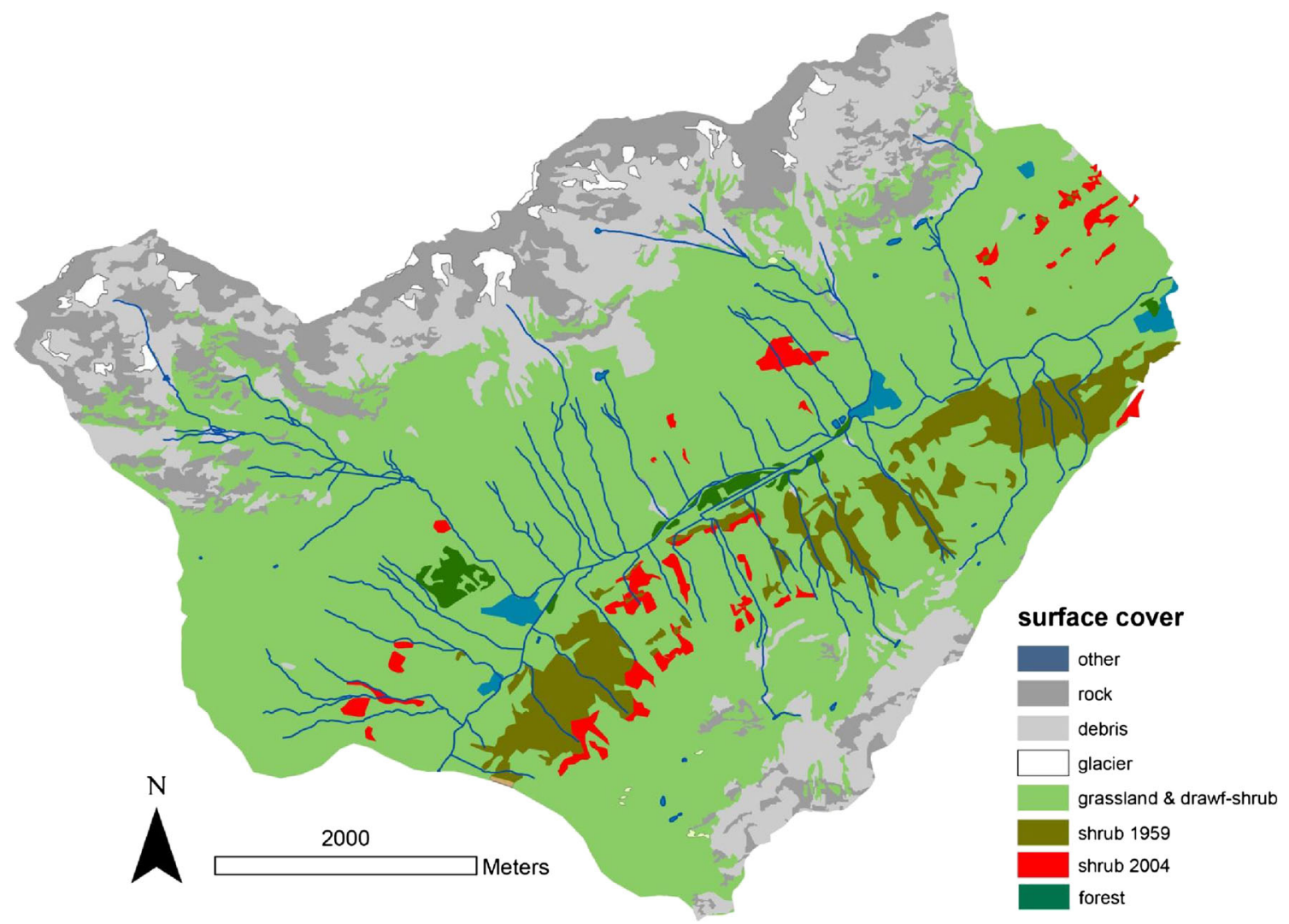

Fig. 10 Invasion of shrubs (mainly Alnus viridis) in the Urseren Valley between 1959 and 2004 
encroachment of shrubs or a re-forestation of sites is a trend in many regions of the European Alps and might partly counteract the described destabilising effects on soils (Alewell and Bebi 2010). These mitigating effects of a warmer climate are most likely small (basically a rising of the tree line). However, the destabilising effects of the combination of climate and changing land use are manifold, suggesting an overall destabilising effect to be likely.

\section{Conclusions}

Soil production and formation rates in undisturbed Alpine grassland are a clear function of soil age. Relatively old soils $(>10-18 \mathrm{kyr})$ have a soil production rate between $54( \pm 14)$ and $113( \pm 30) \mathrm{t} \mathrm{km}^{-2}$ year ${ }^{-1}$. Young and shallow soils $(>1-$ $10 \mathrm{kyr})$ show rates between $119( \pm 44)$ and $248( \pm 91)$ $\mathrm{t} \mathrm{km}^{-2}$ year $^{-1}$ and very young soils $(\leq 1 \mathrm{kyr})$ rates between $415( \pm 242)$ and $881( \pm 520) \mathrm{t} \mathrm{km}^{-2}$ year ${ }^{-1}$. We developed two concepts that might help to determine tolerable soil erosion rates. One is based on the surface age and corresponding soil production rates (that should not be exceeded by soil erosion rates) and the other one on a soil depth that tends to be reached with a specific erosion rate. In the latter case, the question remains unanswered as to what soil depth would still guarantee sustainable land use. Large parts of the Alpine area have a surface age between 10-18 kyr. Using the former concept and considering that erosion is only 50 to $90 \%$ of total denudation then tolerable erosion rates are in the range of 27$102 \mathrm{t} \mathrm{km}^{-2}$ year ${ }^{-1}$.

Soil erosion rates for Alpine grasslands are so far only available from case studies either as point measurements (using e.g. sediment traps and fallout radionuclides such as ${ }^{137} \mathrm{Cs}$ or ${ }^{239+240} \mathrm{Pu}$ isotopes) or as modelled rates of single catchments. Soil erosion magnitude strongly depends on vegetation cover and land use intensity. Measured values were 600 to $3,000 \mathrm{t} \mathrm{km}^{-2}$ year $^{-1}$ ( 0.6 to $3 \mathrm{~mm}$ year $^{-1}$ ) at intensively used grassland sites. Modelled average catchment values (Urseren Valley) resulted in $180 \mathrm{t} \mathrm{km}^{-2}$ year $\left(0.18 \mathrm{~mm}\right.$ year $\left.^{-1}\right)$. These high erosion rates clearly indicate unsustainable land use in many Alpine valleys, particularly if they occur at sites having a high surface age and having comparatively low soil formation rates. Only very young soils having exposed surfaces of parent material might have considerably higher soil formation rates - but soil depth, development and productivity will be low, which also suggests the need for careful and sustainable land management.

In the near future, soil erosion rates can be expected to increase significantly under the combined pressure climate and land use change. This trend might only partly be counteracted by increased stabilization due to the encroachment of bushes (due to the changing land use) and/ or a rise in the tree line (due to climate warming).

Acknowledgments The concept and idea for this manuscript evolved from a workshop in 2012 'Soil erosion in the Alps' which was generously founded by the Swiss Federal Office of Environment and the Swiss Federal Office of Agriculture. We would like to thank especially JeanPierre Clément for his constant efforts to support soil erosion research in the Swiss Alps.

Open Access This article is distributed under the terms of the Creative Commons Attribution License which permits any use, distribution, and reproduction in any medium, provided the original author(s) and the source are credited.

\section{References}

Alewell C, Bebi P (2010) Forest development in the European Alps and potential consequences on hydrological regime. In: Bredemeier M, Cohen S, Godbold DL, Lode E, Pichler V, Schleppi P (eds.) Forest Management and the Water Cycle: An Ecosystem-Based Approach, Ecological Studies 212:111-126

Alewell C, Meusburger K, Brodbeck M, Bänninger D (2008) Methods to describe and predict soil erosion in mountain regions. Landsc Urban Plan 88:46-53

Alewell C, Meusburger K, Juretzko G, Mabit L, Ketterer ME (2014) Suitability of ${ }^{239+240} \mathrm{Pu}$ and ${ }^{137} \mathrm{Cs}$ as tracers for soil erosion assessment in mountain grasslands. Chemosphere 103:274-280

Ammer U, Breitsameter J, Zander J (1995) Contribution of mountain forests towards the prevention of surface runoff and soil-erosion. Forstwiss Centralbl 114:232-249

Anderson SP, von Blanckenburg F, White AF (2007) Physical and chemical controls on the critical zone. Elements 3:315-319

Asselman NEM, Middelkoop H, van Dijk PM (2003) The impact of changes in climate and land use on soil erosion, transport and deposition of suspended sediment in the River Rhine. Hydrol Process 17:3225-3244

Beniston M (2006) Mountain weather and climate: a general overview and a focus on climatic change in the Alps. Hydrobiologia 562:3-16

BFS (2005) Arealstatistik Schweiz: Zahlen - Fakten - Analysen. Bundesamt für Statistik, Neuchâtel, p 99

Bosco C, Rusco E, Montanarella L, Panagos P (2009) Soil erosion in the Alpine area: risk assessment and climate change. Studi Trent Sci Nat $85: 117-123$

Brisset E, Miramont C, Guiter F, Anthony E, Tachikawa K, Poulenard J, Arnaud F, Delhon C, Meunier J-D, Bard E, Sumera F (2013) Nonreversible geosystem destabilisation at $4200 \mathrm{cal}$. BP: sedimentological, geochemical and botanical markers of soil erosion recorded in a Mediterranean Alpine Lake. The Holocene 23:1863-1874

Caviezel C, Kuhn NJ, Meusburger K (2010) Applicability of Alp inspection reports for the reconstruction of land-use and mass wasting history in the Ursern Valley, Switzerland. Erde 141:301-319

Chadwick OA, Brimhall GH, Hendricks DM (1990) From a black to a gray box - a mass balance interpretation of pedogenesis. Geomorphology 3:369-390

Dahms D, Favilli F, Krebs R, Egli M (2012) Soil weathering and accumulation rates of oxalate-extractable phases from alpine chronosequences of up to $1 \mathrm{Ma}$ in age. Geomorphology 151-152: 99-113

Descroix L, Mathys N (2003) Processes, spatio-temporal factors and measurements of current erosion in the French Southern Alps: a review. Earth Surf Process Landf 28:993-1011 
Dixon JL, von Blanckenburg F (2012) Soils as pacemakers and limiters of global silicate weathering. C R Geosci 344:596-609

Dixon JL, Heimsath AM, Amundson R (2009) The critical role of climate and saprolite weathering in landscape evolution. Earth Surf Process Landf 34:1507-1521

Dokuchaev VV (1883) Russian Chernozem. In: Kaner N (ed) Selected works of V. V. Dokuchaev (1967). Int. Program Sci. Transl, Jerusalem, pp 1-419

Dosseto A, Turner SP, Chappell J (2008) The evolution of weathering profiles through time: new insights from uranium-series isotopes. Earth Planet Sci Lett 274:359-371

Dosseto A, Buss H, Suresh PO (2011) The delicate balance between soil production and erosion, and its role on landscape evolution. Appl Geochem 26:S24-S27

Dosseto A, Buss H, Suresh PO (2012) Rapid regolith formation over volcanic bedrock and implications for landscape evolution. Earth Planet Sci Lett 37-338:47-55

Egli M, Norton K, Dahms D (2014) Soil formation rates on silicate parent material in high-mountains: different approaches, different results? Geoderma 213:320-333

Felix R, Johannes B (1995) Bodenerosionsuntersuchungen auf Testparzellen im Kalkhochgebirge. Mitt Osterr Geogr G 137:76-92

Frankenberg P, Geier B, Proswitz E, Schütz J, Seeling S (1995) Untersuchungen zu Bodenerosion und Massenbewegungen im Gunzesrieder Tal/Oberallgäu. Eur J Forest Res 114:214-231

Frei C, Calanca P, Schär C, Wanner H, Schaedler B, Haeberli W et al (2007) Basic principles of climate change. In Fuhrer J, Beniston M, Fischlin A, Frei C, Goyette S, Jasper K et al (eds) Climate change and Switzerland - 2050. Expected impacts on environment, society and economy, OcCC Report. Bern: OcCC/ ProClim

Fuhrer J, Beniston M, Fischlin A, Frei C, Goyette S, Jasper K, Pfister C (2006) Climate risks and their impact on agriculture and forests in Switzerland. Clim Chang 79:79-102

Gellrich M, Zimmermann NE (2007) Investigating the regional-scale pattern of agricultural land abandonment in the Swiss Mountains: a spatial statistical modelling approach. Landsc Urban Plan 79:6576

Gisler S, Liniger H, Prasuhn V (2010) Technisch-wissenschaftlicher Bericht zur Erosionsrisikokarte der landwirtschaftlichen Nutzfläche der Schweiz im 2x2-Meter-Raster (ERK2)

Goodman AY, Rodbell DT, Seltzer GO, Mark BG (2001) Subdivision of glacial deposits in southeastern Peru based on pedogenetic development and radiometric ages. Quat Res 56:31-50

Green EG, Dietrich WE, Banfield JF (2006) Quantification of chemical weathering rates across an actively eroding hillslope. Earth Planet Sci Lett 242:155-169

Grossman RB, Berdanier CR (1982) Erosion tolerance for cropland: application of the soil survey data base. In: Schmidt BL, Allamaras RR, Mannering JV, Papendick RI (eds) Determinants of soil loss tolerance. American Society Agronomy and Soil Science Society of America, Madison (WI), pp 113-130

He L, Tang Y (2008) Soil development along primary succession sequences on moraines of Hailuogou Glacier, Gongga Mountain, Sichuan, China. Catena 72:259-269

Heimsath AM (2014) Limits of soil production? Science 343:617-618

Heimsath AM, Dietrich WE, Nishiizumi K, Finkel RC (1997) The soil production rate function and landscape equilibrium. Nature 388: 358-361

Heimsath AM, Dietrich WE, Nishiizumi K, Finkel RC (2001) Stochastic processes of soil production and transport: erosion rates, topographic variation and cosmogenic nuclides in the Oregon coast range. Earth Surf Process Landf 26:531-552

Heimsath AM, Fink D, Hancock GR (2009) The 'humped' soil production function: eroding Arnhem Land, Australia. Earth Surf Process Landf 34:1674-1684
Heimsath AM, DiBiase RA, Whipple KX (2012) Soil production limits and the transition to bedrock-dominated landscapes. Nat Geosci 5: $210-214$

Isselin-Nondedeu F, Bedecarrats A (2007) Influence of alpine plants growing on steep slopes on sediment trapping and transport by runoff. Catena 71:330-339

IUSS Working Group WRB (2007) World Reference Base for Soil Resources (2nd ed.). World Soil Resources Reports No. 103, First update, FAO, Rome

Ivy-Ochs S, Schäfer J, Kubik PW, Synal HA, Schlüchter C (2004) Timing of deglaciation on the northern Alpine foreland (Switzerland). Eclogae Geol Helv 97:47-55

Jann B (2005) Einführung in die Statistik. 2. bearbeitete Auflage. Oldenburg Wissenschaftsverlag, München

Jenny H (1941) Factors of soil formation. McGraw-Hill, New York

Johnson LC (1987) Soil loss tolerance: fact or myth? J Soil Water Conserv 42:155-160

Kägi HU (1973) Die traditionelle Kulturlandschaft im Urserental; Beitrag zur alpinen Kulturgeographie. PhD Thesis, University of Zurich

Konz N, Schaub M, Prasuhn V, Baenninger D, Alewell C (2009) Caesium-137 based erosion-rate determination of a steep mountainous region. J Plant Nutr Soil Sci 172:615-622

Konz N, Bänninger D, Konz M, Nearing M, Alewell C (2010) Process identification of soil erosion in steep mountain regions. Hydrol Earth Syst Sci 14:675-686

Konz N, Prasuhn V, Alewell C (2012) On the measurement of Alpine Soil Erosion on Plot scale. Catena 91:63-71

Labhart TP (1977) Aarmassiv und Gotthardmassiv. Sammlung Geologischer Führer, vol 63. M. P., Borntraeger, Berlin

Langenscheidt E (1995) The Jenner area of the Berchtesgaden-NationalPark-short description and results of soil-erosion monitoring. Forstwiss Centralbl 114:282-284

Larsen JL, Almond PC, Eger A, Stone JO, Montgomery DR, Malcolm B (2014) Rapid soil production and weathering in the Southern Alps, New Zealand. Science 343:637-640

Lasanta T, Gonzaléz-Hildalgo JC, Vicente-Serrano SM, Sferi E (2006) Using landscape ecology to evaluate an alternative management scenario in abandoned Mediterranean mountain areas. Landsc Urban Plan 78:110-114

Li L, Du S, Wu L, Liu G (2009) An overview of soil loss tolerance. Catena 78:93-99

Ma L, Chabaux F, Pelt E, Blaes E, Jin L, Brantley S (2010) Regolith production rates calculated with uranium-series isotopes at Susquehanna/Shale Hills Critical Zone Observatory. Earth Planet Sci Lett 297:211-225

Mabit L, Meusburger K, Fulajtar E, Alewell C (2013) The usefulness of 137Cs as a tracer for soil-erosion assessment: a critical reply to Parsons and Foster (2011). Earth Sci Rev 127:300-307

Mailänder R, Veit H (2001) Periglacial cover-beds on the Swiss Plateau: indicators of soils, climate and landscape evolution during the Late Quaternary. Catena 45:251-272

Maurin JC, Gilbert F, Robert M, Churlaud C (2005) L'érosion chimique et l'érosion mécanique à long terme du substrat granitique (Vendée, France). Compt Rendus Geosci 337:841-848

MeteoSwiss, Federal Office of Meteorology and Climatology (2013) IDAweb: the data portal of MeteoSwiss for research and teaching. www.meteoschweiz.admin.ch/web/en/services/data portal/idaweb. html. Accessed 1 July 2013

Meusburger K, Alewell C (2008) Impacts of anthropogenic and environmental factors on the occurrence of shallow landslides in an alpine catchment (Urseren Valley, Switzerland). Nat Hazard Earth Syst 8: 509-520

Meusburger K, Alewell C (2009) On the influence of temporal change on the validity of landslide susceptibility maps. Nat Hazards Earth Syst Sci 9:1495-1507 
Meusburger K, Alewell C, Bänninger D (2010) Estimating vegetation parameter for soil erosion assessment in an alpine region by means of QuickBird data. Int J Appl Earth Obs Geoinf 12:201-207

Meusburger K, Schaub M, Konz N, Mabit L, Alewell C (2011) Combined use of $137 \mathrm{Cs}$ and stable isotopes to assess soil degradation in mountainous grasslands of Switzerland. IAEA Soils Newsl 33:14-16

Meusburger K, Steel A, Panagos P, Montanarella L, Alewell C (2012) Spatial and temporal variability of rainfall erosivity factor for Switzerland. Hydrol Earth Syst Sci 16:167-177

Minasny B, McBratney AB, Salvador-Blanes S (2008) Quantitative models for pedogenesis - a review. Geoderma 144:140-157

Mourier B, Poulenard J, Carcaillet C, Williamson D (2010) Soil evolution and subalpine ecosystem changes in the French Alps inferred from geochemical analysis of lacustrine sediments. J Paleolimnol 44: 571-587

Norton KP, von Blanckenburg F, Kubik PW (2010) Cosmogenic nuclidederived rates of diffusive and episodic erosion in the glacially sculpted upper Rhone Valley, Swiss Alps. Earth Surf Process Landf 35:651-662

Phillips JD (1993) Stability implications of the state factor model of soils as a nonlinear dynamical system. Geoderma $58: 1-15$

Piégay H, Walling DE, Landon N, He QP, Liébault F, Petiot R (2004) Contemporary changes in sediment yield in an alpine mountain basin due to afforestation (The upper Drome in France). Catena 55:183-212

Riebe CS, Kirchner JW, Granger DE, Finkel RC (2001) Strong tectonic and weak climatic control of long-term chemical weathering rates. Geology 29:511-514

Riebe CS, Kirchner JW, Finkel RC (2003) Long-term rates of chemical weathering and physical erosion from cosmogenic nuclides and geochemical mass balance. Geochim Cosmochim Acta 67:44114427

Riebe CS, Kirchner JW, Finkel RC (2004a) Sharp decrease in long-term chemical weathering rates along an altitudinal transect. Earth Planet Sci Lett 218:421-434

Riebe CS, Kirchner JW, Finkel RC (2004b) Erosional and climatic effects on long-term chemical weathering rates in granitic landscapes spanning diverse climate regimes. Earth Planet Sci Lett 224:547-562

Sauer D (2010) Approaches to quantify progressive soil development with time in Mediterranean climate-I, Use of field criteria. J Plant Nutr Soil Sci 173:822-842

Sauer D, Wagner S, Brückner H, Scarciglia F, Mastronuzzi G, Stahr K (2010) Soil development on marine terraces near Metaponto (Gulf of Taranto, southern Italy). Quatern Int 222:48-63

Scheurer K, Alewell C, Bänninger D, Burkhardt-Holm P (2009) Climate and land-use changes affecting river sediment and brown trout in alpine countries - a review. Environ Sci Pollut Res 16:232-242
Schneeberger N, Bürgi M, Kienast PDF (2007) Rates of landscape change at the northern fringe of the Swiss Alps: historical and recent tendencies. Landsc Urban Plan 80:127-136

Schwarz M, Zimmermann NE, Wildi O, Kienast F (2004) Mapping of land cover continuous fields using MODIS data in Switzerland. Bot Helv 114:151-167

Shaw CF (1930) Potent factors in soil formation. Ecology 11:239-245

Sommer M, Gerke HH, Deumlich D (2008) Modelling soil landscape genesis - a "time split" approach for hummocky agricultural landscapes. Geoderma 145:480-493

Sparovek G, Jong van Lier Q (1997) Definition of tolerable soil erosion values. Rev Bras Cienc Solo Viçosa 21:467-471

Swiss Federal Statistical Office (2001) The changing face of land use. Land use statistics of Switzerland. Swiss Federal Statistical Office, Neuchâtel

Tasser E, Walde J, Tappeiner U, Teutsch A, Noggler W (2007) Land-use changes and natural reforestation in the Eastern Central Alps. Agric Ecosyst Environ 118:115-129

Troxler J, Chatelain C, Schwery M (2004) Technical and economical evaluation of grazing systems for high altitude sheep pastures in Switzerland. Grassl Sci Eur 9:590-592

Ugolini FC, Corti G, Dufey JE, Agnelli A, Certini G (2001) Exchangeable $\mathrm{Ca}, \mathrm{Mg}$, and $\mathrm{K}$ of rock fragments and fine earth from sandstone and siltstone derived soils and their availability to grass. J Plant Nutr Soil Sci 164:309-315

Verheijen FGA, Jones RJA, Rickson RJ, Smith CJ (2009) Tolerable versus actual soil erosion rates in Europe. EarthSci Rev 94:23-38

Waroszewski J, Kalinski K, Malkiewicz M, Mazurek R, Kozlowski G, Kabala C (2013) Pleistocene-Holocene cover-beds on granite regolith as parent material for Podzols - an example from the Sudeten Mountains. Catena 104:161-173

West AJ, Galy A, Bickle M (2005) Tectonic and climatic controls on silicate weathering. Earth Planet Sci Lett 235:211-228

White AF (1995) Chemical weathering rates of silicate minerals in soils. In: White AF, Brantley SL (eds) Chemical Weathering Rates of Silicate Minerals. Reviews in Mineralogy 31, Mineralogical Society of America, pp 407-461

Yoo K, Mudd SM (2008) Toward process-based modelling of geochemical soil formation across diverse landforms: a new mathematical framework. Geoderma 146:248-260

Yoo K, Amundson R, Heimsath AM, Dietrich WE, Brimhall GH (2007) Integration of geochemical mass balance with sediment transport to calculate rates of soil chemical weathering and transport on hillslopes. J Geophys Res 112, F02013. doi:10.1029/2005JF000402 